\title{
O insight originário de Fichte
}

Dieter Henrich

\section{(2) OpenEdition}

Journals

Edição electrónica

URL: https://journals.openedition.org/ref/1821

DOI: 10.4000/ref.1821

ISSN: 2258-014X

\section{Editora}

EuroPhilosophie Editions

Refêrencia eletrónica

Dieter Henrich, «O insight originário de Fichte», Revista de Estud(i)os sobre Fichte [Online], 22 | 2021, posto online no dia 01 dezembro 2021, consultado o 05 março 2022. URL: http:// journals.openedition.org/ref/1821 ; DOI: https://doi.org/10.4000/ref.1821

Este documento foi criado de forma automática no dia 5 março 2022

(c) EuroPhilosophie 


\title{
O insight originário de Fichte
}

\author{
Dieter Henrich
}

\section{NOTA DO EDITOR}

Já de início é preciso prestar esclarecimento sobre a escolha do título de "O insight originário de Fichte" para "Fichtes ursprüngliche Einsicht", particularmente no que concerne ao substantivo alemão Einsicht. Trata-se de um substantivo oriundo do verbo einsehen, verbo composto de sehen (ver) e do prefixo ein (que indica movimento para dentro, de entrada), daí que tanto o verbo como o substantivo têm uma miríade de significações, como compreender, ver com penetração, discernir, no caso do verbo, e compreensão, visão, discernimento e mesmo intuição, no caso do substantivo. Para evitarmos um uso equívoco do termo 'intuição', ou nos aventurarmos na confecção de neologismos problemáticos, optamos por vertê-lo como insight - termo do inglês já assimilado em nossa língua - quando Henrich o utiliza para designar o pensamento que está na origem de toda a filosofia de Fichte e a percorre como um fio vermelho, porque é o termo que mais se aproxima daquilo que Henrich tem em mente com a Einsicht originária de Fichte: uma iluminação, a compreensão de um problema pela súbita captação de seus elementos, como nos diz o Houaiss, e que é originária justamente porque, estando em sua base, define sua natureza e seu desenvolvimento. Como mostra Henrich, o insight originário é uma "descoberta" feita por Fichte para os problemas teóricos da fundação da filosofia a partir do eu e da autoconsciência, como seu princípio, problemas nos quais ele estava imerso. Nos demais casos de Einsicht, a tradução se dá conforme o contexto, podendo ser compreensão, discernimento ou mesmo visão.

O texto foi originalmente publicado em Henrich, D., Wagner, H. (1966) Subjektivität und Metaphysik: Festschrift fur Wolfgang Cramer. Frankfurt am Main: Vittorio Klostermann. Nossa tradução indicará entre colchetes a paginação original dessa primeira publicação. Há uma segunda impressão em separata no ano seguinte, na coleção Wissenschaft und Gegenwart, Heft 34, também editada por Klostermann. Em 2019 surge uma reedição inalterada, acompanhada de um longo estudo feito pelo autor, 
bem posterior, sobre os mesmos temas: Henrich, D. (2019) Dies Ich, das viel besagt:

Fichtes Einsicht nachdenken. Frankfurt am Main: Klostermann.

Tradução, revisão e notas de Francisco Prata Gaspar (UFSCar) e Thiago Suman Santoro

(UFG).

\section{Introdução}

1 'Autoconsciência' é o princípio do pensamento de Fichte. Só esse detalhe já é suficiente para que o presente não lhe dê ouvidos. Afinal, a filosofia atual, assim como a arte atual, surgiu da desconfiança em relação ao tom patético do discurso sobre o eu. Ela lhe contrapôs o concretum da 'existência' e a análise objetiva da linguagem. Daí que a fama de Fichte só se baseia ainda na pálida lembrança de uma tradição à qual cabe uma admiração frequentemente alegada apenas com muito esforço.

2 Por isso, é difícil representar o pensamento de Fichte não apenas como um documento da história, mas como uma contribuição ao discernimento. Isso, entretanto, é o que deverá se dar a seguir. Deve-se mostrar que Fichte, no início de seu percurso de vida filosófica, realizou uma descoberta. Primeiramente, ela não foi tanto a constatação de um fato, mas a de uma dificuldade, de um problema: ele compreendeu que a 'autoconsciência', à qual já há muito tempo antes dele a filosofia tinha recorrido como fundamento do conhecimento, só pode ser pensada sob condições que anteriormente ainda não tinham sido consideradas. Esse problema tornou-se fio condutor de suas reflexões, antes mesmo que ele pudesse formulá-lo explicitamente. No sinuoso caminho de sua doutrina da ciência, ele chegou próximo da solução. Ali onde não a atingiu, ele levou bem adiante a colocação da questão - tão longe que segui-lo é, mesmo hoje, um aprendizado ainda. Quem procura por um conceito adequado de 'autoconsciência' tem de retornar a Fichte e ao seu ainda incompreendido conhecimento. Tal conhecimento foi injusta e precocemente obscurecido pela hermética apodicidade de sua retórica e pela poderosa sombra de Hegel.

3 [189] O caminho de fundamentação dessa tese deve, ao mesmo tempo, contribuir para diferenciar a relação da filosofia atual com Fichte e com o idealismo em geral. Ainda é válida, em geral, a ideia de que o lugar histórico de seu pensamento é o de uma amplificação da consciência moderna, que pouco depois entra em sua crise. A filosofia do eu é tomada como a teoria de uma equação que identifica ipseidade (Selbstsein) e autopoder (Selbstmacht). Sua gênese aparece como um processo de crescente arrogância e presunção da subjetividade. É com Descartes que ela deve ter começado, mas é em Fichte que alcança seu apogeu. Ao lado dessa determinação do lugar histórico de Fichte, é destinado a ele apenas o significado de ter contribuído em algo para o desdobramento da dialética de Hegel.

4 Em tal avaliação, o conteúdo objetivo da sua doutrina permanece na sombra, tanto quanto os motivos que a impulsionaram. Se, no entanto, eles se tornam visíveis, também desaparece então a impressão de que com essa imputação à pretensa hybris do espírito moderno foi enunciado algo de relevante. Essa imputação resulta da autoilusão de um presente que sempre tem a mais viva necessidade de se definir em oposição à sua origem e que, com isso, desconhece o que lhe preparou o caminho e a quem ele tem de estar ligado no interesse de sua autocompreensão. Para quem se introduz na temática de Fichte, aquele diagnóstico do mundo moderno que reconhece na fórmula de 
Nietzsche sobre a equivalência entre niilismo e vontade de poder sua suprema expressão filosófica, e no Fichte do eu absoluto seu precursor, perde, junto com o diagnóstico global acerca da filosofia deste, seu poder de convencimento. 0 interesse no insight originário de Fichte diz respeito, por isso, não somente a um importante tema da teoria filosófica. Ele diz respeito à possibilidade de uma filosofia que está em uníssono com os traços fundamentais da consciência atual.

5 No que se segue, este interesse será posto porém em segundo plano. As dificuldades de trazer a temática de Fichte à discussão são grandes o suficiente. Em boa parte, elas resultam da composição dos textos. 0 próprio Fichte levou a público poucas obras. Somente uma delas desenvolve a fundação de sua filosofia, a doutrina da ciência de 1794. Mas para esta também vale aquilo que pode ser dito sobre todas as suas preleções: que sua concepção era modificada durante a escrita. [190] Assim, Fichte se opunha a toda tentativa de aprisioná-lo à letra de suas obras, com o conselho de se colocar no ponto de vista do todo, pois a execução é quase sempre deficiente. Ainda em seus últimos anos, ele acreditou ter apreendido e exposto a ideia da doutrina da ciência mais claramente do que nunca. Sob tais circunstâncias, é compreensível que até agora ainda não tenha sido realizada uma interpretação pormenorizada de Fichte, e é de se supor que, mesmo com um destino mais favorável de sua repercussão, ela dificilmente poderia ter surgido antes. $O$ cenário é dominado por exposições gerais, interpretações tendo Hegel em vista e biografias eruditas do agitado ambiente da época. Análises como a de Gueroult ou de Gurwitsch quase não encontraram acolhimento e sequência ${ }^{1}$.

6 Mesmo o que pode ser feito hoje não pode ser mais que uma preparação para uma compreensão futura. Cerca da metade da obra de Fichte consiste no espólio até agora ainda não decifrado. A edição sobre a qual temos de nos apoiar oferece a maioria das doutrinas da ciência em uma versão retrabalhada pelo filho. Por isso, nenhuma interpretação, sem exceção, tem por base textos confiáveis. ${ }^{2}$ A recomendação de Fichte, de partirmos da ideia do todo, também tem de ser considerada a partir desse motivo.

7 Assim, a análise que se segue é orientada, por muitas razões, mais à coisa (Sache) que aos textos. $\mathrm{O}$ insight originário de Fichte será compreendido e discutido como uma contribuição à teoria da autoconsciência. Disto resultará ao mesmo tempo que o desenvolvimento da doutrina da ciência também pode e tem de ser interpretado como uma progressiva análise de um conceito do eu. Quem não compreende essa progressão, também pouco poderá contribuir à interpretação histórica da obra de Fichte e sua biografia filosófica. Ele é especialmente incapaz de adquirir uma posição segura ante a conhecida questão cardinal: se e em que sentido se deve notar ali uma transformação fundamental. Contudo, mesmo a interpretação histórica e a exegese dos textos são tarefas de um peso próprio. Depois de primeiramente desconsiderá-los, dever-se-á também, ao final, contribuir para sua solução.

\section{0 eu é reflexão de si mesmo}

8 [191] Pode-se dividir o caminho histórico do surgimento de uma teoria da autoconsciência em várias épocas. No início da terceira época encontra-se o lugar próprio de Fichte. Após uma pré-história, que vai desde a antiguidade tardia até o começo da modernidade, Descartes foi quem primeiro fez do eu o princípio da filosofia. Ele encontrou no eu o fundamento da evidência de todo conhecimento possível. Leibniz foi mais adiante e viu que a autoconsciência é o modelo dos conceitos metafísicos 
fundamentais de força e substância. Desse modo, ela se tornou fundamento do conteúdo e não apenas da certeza da ontologia. Depois, John Locke ensinou, por outro lado, que o 'eu' é apenas um ato de identificação consigo mesmo. Com isso, foi interditada a possibilidade de empregar conceitos ontológicos, que por ventura podem ser extraídos da autoconsciência, para definir esta retroativamente. O polissêmico eu de Leibniz tornou-se uma entidade enigmática sem lugar, sobre cuja existência Hume levantou suas dúvidas. Com efeito, Jean Jacques Rousseau seguiu Locke, ao enunciar que a autoconsciência é a pressuposição daquela ligação que produzimos quando julgamos. Através dele o eu se tornou princípio da teoria da lógica. E ao seu estímulo seguiu Kant. Ele fez do eu o 'ponto supremo' da filosofia transcendental, ao qual têm de estar atados, primeiro, toda a lógica e, depois dela, a doutrina do conhecimento dos objetos.

Todas essas teorias têm em comum a autoconsciência como tema por excelência. Também nelas ela é entendida quase universalmente como princípio a partir do qual outro saber pode ser fundado. Exatamente porque prevalece o interesse em sua função de fundamentação, a autoconsciência não é, todavia, examinada naquilo que ela é em si mesma e em como ela pode ser pensada enquanto tal. São examinadas suas relações com outros termos, em virtude das quais ela é o princípio fundante - em Descartes, da evidência, em Leibniz, das categorias, em Rousseau e em Kant, dos juízos.

Apesar dessa limitação do campo de investigação e a despeito também da diversidade de suas teses, é a mesma representação da estrutura do eu que conduz todas essas teorias. Kant a enunciou e ocasionalmente a discutiu: ele pensa o eu como aquele ato no qual o sujeito do saber abstrai de todos os objetos particulares [192], volta-se a si mesmo e, assim, percebe a unidade contínua de si consigo mesmo. No caso único da autoconsciência, pensar e pensado, ter e tido, noesis e noema não se diferenciam um do outro. Onde o eu está, ali estão ambos, o sujeito e esse sujeito enquanto seu objeto. Nós nunca podemos nem mesmo apreender o eu-sujeito para si mesmo como um fato qualquer. Onde nós o pensamos, já o pressupusemos no nosso próprio pensamento e, com isso, fizemos do eu-sujeito pensado um objeto. Só podemos, portanto, girar em torno dele em um círculo constante. Essa circunstância tem por consequência o fato de que na autoconsciência não ocorre por si nenhuma ampliação de nosso conhecimento da realidade. 0 sujeito do saber (das Wissende) já contém o que ele capta nesse retorno sobre $\mathrm{si}^{3}$.

11 Que esse retorno sobre si é sua própria ação, pode ser facilmente concluído, segundo a opinião de Kant, da estrutura da autoconsciência. “A expressão 'eu penso' (esse objeto) já indica que eu, em relação à representação, não sou passivo." 4 A palavra 'eu' denota o atuante de uma atuação (den Vollziehenden eines Vollzuges). Ora, se esse próprio sujeito é objeto de seu saber, então é justamente em virtude de sua subjetividade ativa.

12 Todos os antecessores de Kant teriam encontrado em tais proposições uma elucidação de suas representações sobre o eu. Reduzindo-as a uma breve fórmula, pode-se denominá-las a teoria da essência do eu como reflexão. Ela admite, primeiramente, um sujeito do pensamento e enfatiza que esse sujeito permanece em uma contínua relação consigo mesmo. Em segundo lugar, ademais, ela afirma que essa relação se realiza à medida que o sujeito faz de si seu próprio objeto, volta a si mesmo a atividade do representar, que originariamente está referida aos objetos, e desse modo produz, então, o único caso de uma identidade entre atividade e produto da atividade ${ }^{5}$.

[193] Essa representação parece ser evidente e, no entanto, é exatamente o contrário disso. Não é o eu, mas sim a teoria do eu como reflexão que se movimenta 
continuamente em círculo em torno de si mesma. Isso se torna manifesto pelo embaraço no qual ela cai quando dirigimos a ela questões simples. Faremos a ela duas dessas questões. Sobretudo a primeira colocaremos juntamente com Fichte. Com ela, iniciou-se uma nova época da teoria da autoconsciência, no interior da qual a estrutura do eu é o tema propriamente dito.

14 Em primeiro lugar, perguntamos: a teoria do eu-reflexão fala de um eu-sujeito que conhece a si mesmo ao entrar em relação consigo mesmo - ao voltar-se a si mesmo. Como é possível pensar esse sujeito? Se admitimos que ele é efetivamente um eu na função do sujeito, então é manifesto que nós nos movemos em círculo e pressupomos o que queremos explicar. Pois só se pode falar de um eu ali onde um sujeito apreendeu a si próprio - onde o eu diz para si mesmo 'eu'. o que distingue justamente a autoconsciência de todo outro saber é o fato de que nela o mesmo estado de coisas aparece num duplo valor posicional. Qualquer que seja o ato pelo qual essa consciência é produzida, 'eu' pode ser denominado somente o resultado total no qual o eu é obtido de si mesmo no modo do saber. Esse ato, contudo, não pode ser inteiramente descrito como reflexão. Pois 'reflexão' só pode significar que um saber já dado é apreendido expressamente e, com isso, tornado explícito. A teoria da reflexão do eu, no entanto, [194] quer explicar não a clareza, mas sim a origem da autoconsciência. Através dessa pretensão ela cai em seu círculo. Ela pode apenas ignorá-lo, mas nunca escapar dele. 0 eu deve ser aquele que, refletindo, volta a si. Portanto, aquele que empreende a reflexão tem de ser ele próprio já ambos, aquele que sabe e o que é sabido (Wissendes und Gewußtes). o sujeito da reflexão realiza, com isso, a igualdade completa eu=eu. E no entanto, só através da reflexão deveria se dar essa igualdade.

15 Não é possível evitar esse resultado com a admissão de que o eu-sujeito não deva ser pensado propriamente como um eu - de que a autoconsciência seja justamente consequência da reflexão. Uma tal tentativa de fuga fracassa rapidamente, a saber: se o eu-sujeito é algo outro que um eu, então ele nunca pode chegar, no caminho da reflexão, à unidade da consciência eu=eu. A autoconsciência consiste na identidade de seus relata. Se a relação é interpretada através da reflexão e, por conseguinte, como uma performance através da qual o ato, que efetua a reflexão, torna-se consciente de si mesmo, então ou o sujeito do ato tem de ser ele próprio já um eu, ou então a igualdade eu=eu não é alcançada. Se o eu-sujeito não é um eu, também o eu sabido, o eu-objeto, jamais pode ser idêntico a ele.

16 Assim, a teoria da reflexão da autoconsciência ou pressupõe o fenômeno-eu como não explicado, ou então ela o estilhaça.

17 Uma segunda pergunta conduz à constatação da mesma deficiência ${ }^{6}$ : a teoria da reflexão admite que o eu obtém o conhecimento de si por um retorno a si. Ora, não basta, porém, que algum sujeito adquira de algum objeto uma consciência explícita, para explicar a consciência eu=eu. Esse sujeito também tem de saber que seu objeto é idêntico ao próprio sujeito. $O$ conhecimento dessa identidade não pode pertencer a ele por nenhum relato de uma terceira instância. Afinal, o fenômeno da autoconsciência atesta uma relação imediata consigo mesmo. E a teoria do eu-reflexão assume, em concordância com esse fenômeno, que o eu se apreende unicamente por meio de seu retorno a si. Reflexão significa autorrelação, não relação a um terceiro que dá a conhecer: 'aqui alguém captou a si mesmo'. É desse modo que Mefistófeles se diverte quando os bêbados colocam suas facas em seus próprios [195] narizes, os quais eles tomam por doces uvas. $\mathrm{O}$ eu, contudo, é seu próprio demônio, ao qual Mefisto não pode 
ocultar nada. Ele sabe de si originariamente, não através de persuasão ou sutis inferências. Como, entretanto, a autoconsciência pode saber que captou a si mesma, se através da reflexão do eu surgiu um eu-objeto? Evidentemente, ela só o pode se ela já sabe de si previamente. Pois somente a partir de tal saber é possível a ela dizer: o que eu apreendo sou eu próprio. Mas se ela já sabe de si, então ela já está no estado do saber eu=eu. E desse modo, a teoria da reflexão termina, pela segunda vez, em uma petitio principii. Ela pressupõe a completa solução do problema que lhe foi destinado.

Fichte foi o primeiro que reconheceu esse círculo e dele extraiu consequências. No seu entender, todos os que nele caem cometem o erro de representar o eu somente como um objeto entre outros. Pode-se esclarecer a posição de Fichte da seguinte maneira: a teoria da reflexão, decerto, leva em conta o eu-sujeito, mas, então, ela o pensa somente como uma força que é capaz de atuar sobre si. Com isso, o sentido mais característico da subjetividade na autoconsciência é abandonado. A autoconsciência é interpretada por meio de uma atuosidade fática, que tem seu lugar na esfera dos objetos. Quem a pensa, sempre já pressupõe, por isso, um sujeito pensante (a saber, seu próprio), para o qual ela é objeto. Ele deixa, portanto, de pensar o eu-sujeito nele mesmo e de se colocar efetivamente na perspectiva de uma autorrelação cognoscente (wissende Selbstbeziehung). Ao contrário, ele fala sobre a autoconsciência do ponto de vista de um saber que nunca tematiza a si próprio. E justamente por isso ele não vê nada de estranho em pensar o eu como relação reflexiva da atividade fática, e não da atividade cognoscente (wissender Tätigkeit). É só essa cegueira que possibilita o uso do modelo reflexivo. Ao mesmo tempo, ela impede a compreensão de que esse modelo se move em círculo e que este círculo, no interior dele, é inevitável.

Nós nos tornamos conscientes da consciência de nossa consciência (...) somente por fazermos dela novamente objeto e obtermos, através disso, a consciência da consciência de nossa consciência, e assim sucessivamente ao infinito. - Desse modo, no entanto, nossa consciência não foi explicada ou não há, em consequência disso, nenhuma consciência, já que se admite a consciência como estado da mente ou como objeto e se pressupõe, por isso, um [196] sujeito que porém nunca se encontra. Essa sofistaria se encontrou até agora no fundamento de todos os sistemas - até mesmo do kantiano."7

Ora, a teoria da reflexão, certamente, não só tem uma pressuposição em uma orientação inadequada do pensar, mas também uma fundamentação no fenômeno do eu. Ela tem em vista o que efetivamente se deixa mostrar: um saber, que está encerrado em suas experiências e opiniões do que acontece, emerge a partir dessa mundanidade aparentemente abrangente e torna-se para si mesmo tema e questão. Ao fazer isso, esse saber sabe que apenas ele sozinho pode se certificar de si mesmo, logo, que ele é o sujeito da sua ipseidade (Selbstsein) consciente. Esse ato bem pode ser descrito como reflexão. É razoável também procurar nele o fundamento da possibilidade de toda reflexão. Todavia, ele já pressupõe a ipseidade originária. Só a partir dessa ipseidade é possível que um eu se desprenda do encadeamento do mundo e se apreenda expressamente como aquilo que ele já tem de ter sido anteriormente: saber de si enquanto subjetividade que sabe (wissender Subjektivität). É a partir da essência originária do eu que tem de ser compreendida a possibilidade da reflexão. A teoria da reflexão procede inversamente e explica o eu como caso de uma efetuação da reflexão. Portanto, com o auxílio do fenômeno manifesto, mas secundário, ela interpreta a essência originária, porém obscura do eu. 
te Fichte conduz a vastas e ricas consequências. No modo como Descartes obteve a fundamentação da metafísica a partir do Ego cogito percebe-se seu espanto diante desse modo único de conhecimento. Também para Leibniz, a polissêmica univocidade do 'ce Moi' era uma ocasião para realizar, admirado, a experiência da natureza incomparável da certeza filosófica. Kant falou do eu no mesmo tom. Ele vê nele o signo de "uma faculdade sublime acima de toda intuição sensível", que "olha para uma infinitude de representações e conceitos que ela mesma engendrou". 'Sublime' significa para ele uma experiência que ultrapassa os limites da compreensibilidade.

21 No entanto, mesmo sua admiração não diz respeito a nenhum enigma e segredo. [197] A partir do conhecimento finito e mundano, o eu aparece, certamente, como o puro e simplesmente assombroso, mas em si mesmo ele é a clareza consumada e o mais familiar para todo o conhecer que obteve clareza sobre si mesmo. Somente ele torna possível que possamos nos familiarizar com o outro. Por isso, Kant, assim como Descartes e Leibniz, não encontra na apreensão da estrutura do eu uma tarefa própria da filosofia. Assim, ele tampouco vê os problemas nos quais um pensamento que compreende o sentido dessa tarefa se enreda.

Fichte levou a teoria da autoconsciência a uma posição inteiramente outra. Entre aquilo que é 'eu' e aquilo a partir do que ele pode se fazer compreensível abre-se uma diferença, talvez até mesmo um abismo. Medi-lo é, doravante, tarefa da filosofia. A teoria da reflexão, que exige o fenômeno do eu para sua própria explicação, não traz o eu completamente à vista. Antes, ela o leva, por fim, ao desaparecimento. Tem-se, portanto, de procurar uma outra teoria que vá ao fundamento do fenômeno. Não se pode encontrá-la antes que se descreva mais completamente a autoconsciência e se deixe, então, levar por ela ao embaraço ao interpretá-la.

Fichte se expôs a esse embaraço. Em certo sentido, é possível dizer que ele nunca se livrou dele. Os estágios no desenvolvimento da doutrina da ciência são as muitas tentativas de encontrar o fundamento do fenômeno em uma teoria, cuja problemática ele tinha entendido - a de compreender sua possibilidade e sua conexão interna.

Ele expressou os pensamentos centrais de uma tal teoria em três fórmulas, cuja fundamentação é dominada pelas partes essenciais de sua obra. Cada uma dessas fórmulas marca uma etapa na história da sua ideia fundamental. Cada uma delas compreende uma revisão da anterior. Ao mesmo tempo, todas elas são obtidas a partir da oposição à teoria da autoconsciência como reflexão. A linguagem de Fichte opõe-se às implicações desse modelo e utiliza, por isso, muitas metáforas de difícil compreensão. O que ele diz parece atestar que nossa linguagem favorece a autointerpretação secundária do eu. Ela oculta, na aparência do modo supostamente transparente de falar, o verdadeiro estado de coisas e a dificuldade de compreendê-lo. Contra a fala natural do eu [198] e, contudo, falando, a filosofia tem de se tornar teoria da autoconsciência. Isso explica por que foi tão difícil e por que Fichte nunca logrou trazer à plena clareza o que estava diante de seus olhos. Assim, ele mais ocultou do que comunicou sua descoberta em textos, os quais pertencem aos mais impenetráveis de toda tradição. Com esforço semelhante àquele que Fichte empregou sobre a própria coisa (Sache), o intérprete tem de extrair esta da espessa mata dos manuscritos nunca completos. 


\section{II. $\mathrm{O}$ eu se põe pura e simplesmente} acontecimento. por si mesmo. palavrinha "eu". eu-objeto.

O pensamento fundamental da doutrina da ciência de 1794 é a proposição: o eu põe pura e simplesmente a si mesmo ${ }^{9}$. Com ela, Fichte deu ao pathos da liberdade uma expressão extrema. Seus contemporâneos perceberam-na como a justificação dos ideais da revolução, como a expressão da decisão de erigir um mundo sob as condições da razão, como o princípio dos jacobinos de não tolerar nada que não seja sua própria obra. A libertação da humanidade e o triunfo da teoria pareciam ter se tornado um

É verdade que Fichte viveu em meio a tais experiências, que ele também pensou a partir delas. Captar a liberdade foi o motivo que fez dele filósofo. Mas ele não se tornou um pensador ao qual nós ainda podemos dar ouvidos única e exclusivamente através de sua vontade. Não foi pelo toque de clarim do seu discurso sobre o eu, mas pelo pensamento nele proclamado, que a revolução se tornou teoria. Esse pensamento deve e pode falar

Se damos atenção exclusivamente ao pathos da fórmula do eu que põe a si mesmo, então o insight originário de Fichte fica dissimulado. Se temos em vista esse insight, então ele se desprende de todo pathos e ganha os traços até mesmo de um embaraço. A fórmula de Fichte não se refere a um estado de coisas claro como o sol, ao qual se teria apenas de interpretar para se chegar ao fundamento seguro. Ela é o resultado da reflexão de que não resta nenhum outro caminho a não ser o de admitir um fundamento que se subtrai aos nossos olhares, tão logo queiramos conceituar aquilo que todos nós olhamos, na medida em que sabemos de nós mesmos e nos damos a conhecer pela

[199] O discurso sobre o eu que põe a si mesmo é a imagem negativa do modelo da reflexão, cuja deficiência Fichte reconheceu ${ }^{10}$. A teoria da reflexão tinha partido de um eu-sujeito, logo, estava obrigada a pressupô-lo como existente. Provou-se, contudo, que através do retornar do seu raio intencional (Intentionsstrahls) sobre si mesmo não se torna compreensível nenhuma autoconsciência. Assim, parece claro substituir a pressuposição dessa teoria por seu contrário. Disto resulta o pensamento de que não há um eu-sujeito antes da autoconsciência, mas sim que mesmo o sujeito só emerge simultaneamente com toda a consciência eu=eu. A partir do momento-sujeito não foi possível deduzir toda a autoconsciência. Portanto, ela não emergirá a partir de um de seus momentos, mas com todos simultaneamente, como que em um instante,

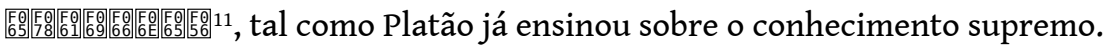

Quando Fichte fala do pôr-se do eu, ele tem em mente, então, essa imediatez na qual todo o eu emerge de uma só vez. "Somente através desse ato, e exclusivamente através dele, através de um agir sobre um agir mesmo, cujo agir determinado não é precedido por nenhum agir em geral, o eu vem a ser originariamente para si." ${ }^{12}$ Por isso, é sem fundamento a objeção que diz que o ponente tem de preceder o pôr. O eu é um pôr, é aquele agir, pelo qual surge seu ser-para-si, um eu-sujeito toma consciência de si como

O pôr do eu é um pôr pura e simplesmente. Isso significa que ele não se dá através de algo previamente já posto ou com referência a um tal. "O eu põe-se pura e simplesmente, i.e., sem nenhuma mediação." ${ }^{13}$ Outro pôr, possivelmente, só faz com que um ato do saber chegue à autoconsciência, ele tem, portanto, o mesmo resultado que uma 
reflexão. O eu permanece incompreensível dessa maneira. Por isso, ele tem de ser pensado como aquele pôr do tipo assinalado. $\mathrm{O}$ discurso de Fichte sobre o 'pôr', jamais definido por ele, é apropriado para formular ambas as coisas em uma só, a saber: que algo emerge pura e simplesmente [200] sem existência anterior, e que, no emergir, entra em relação com o saber. 0 que se põe pura e simplesmente, atinge o ser-para-si sem nenhum outro fundamento.

31 Assim mostra-se que é possível ver na tese do absoluto pôr do eu mais do que uma híbrida presunção que já desde o início priva um pensamento da seriedade e do esforço pela verdade. Tal tese pode ser lida como a clara tentativa de explicar algo cuja existência ninguém pode colocar em dúvida - a realidade da autoconsciência. Mesmo em sua filosofia tardia - a qual abandonou o elevado pathos da primeira -, Fichte jamais encontrou ocasião para duvidar da legitimidade das reflexões que conduziram à primeira doutrina da ciência.

No entanto, ele reviu extensamente essa teoria. É preciso tentar procurar as razões para essa revisão não em motivos exteriores, mas nas deficiências inerentes à própria teoria. Nós as encontraremos se investigarmos mais atentamente a estrutura de um eu que é 'pôr-se'.

Primeiramente, deve-se notar uma diferença formal entre a teoria do 'pôr' e a teoria da reflexão do eu: mesmo o pôr enquanto ato inclui uma relação - aquela entre uma produção e seu produto. Enquanto os relata da reflexão são equivalentes segundo seu conteúdo, no caso do pôr, contudo, vale o contrário. $\mathrm{O}$ eu como sujeito é idêntico ao eu como objeto. A teoria da reflexão não é obrigada a dar-lhes uma significação diferente para além da diferença de sua posição na relação do saber. A bem dizer, ela também não deixa claro como essa relação pode se realizar. Em cada um dos termos ela já está pressuposta. No caso do pôr, ocorre algo totalmente diferente. A produção é tomada aqui como um ato real da atividade, e o produto como saber dele. Por certo, é dito que ambos se tornam reais simultaneamente. A atividade não é sem que ao mesmo tempo seu produto emerja. Ela não se relaciona com ele tal como um choque com um livre movimento por ele causado, mas como uma corrente elétrica com seu campo magnético. No entanto, evidentemente, ela tem de ser distinguida do seu produto. E só esse produto é doravante saber, ao passo que a atividade só há de ser pensada como fundamento do saber se esse fundamento também é apreendido no saber e se a atividade é posta 'para-si'.

[201] Encontra-se aqui uma das pressuposições para a mudança tardia de Fichte: o fato de que saber e fundamento do saber são diferentes um do outro na autoconsciência em geral é condição para que se possa separá-los radicalmente entre si, de modo que o fundamento do saber no eu não é mais o que é sabido. Fichte chegou a este passo somente através de vários pensamentos intermediários. A doutrina de 1794 ainda não extrai consequências da heterogeneidade dos relata no seu conceito de eu. Ela sugere a representação de que 'eu' está em toda parte onde um impulso de ação retorna a si mesmo, e é, portanto, um 'agir sobre si mesmo'. O saber da autoconsciência, então, é pensado como o choque do ato voltado a si com sua própria atuosidade (Aktuosität). Vêse que elementos da teoria da reflexão se insinuam em seu contraprojeto. A relação reflexiva não é tomada como o produto do pôr, tal como seu conceito propriamente o exige. Ela aparece como a própria efetuação dele. Com isso, certamente é assegurado no contraprojeto à teoria da reflexão que o agente já não é admitido como cognoscente (Wissendes): o saber só deve surgir a partir da produção; mas não se vê, entretanto, 
como um saber pode se tornar compreensível a partir do encontro consigo da produção. Isso, porém, seria necessário, se a ipseidade do eu devesse ser compreendida a partir de tal produção.

Ora, Fichte tem graves e importantes razões para qualificar essa ação, que conduz à consciência 'eu', como o objeto real dessa consciência. A experiência no efetuar (Vollzug) da autoconsciência fornece essas razões. Seu efetuar pode nos ser atribuído. Mas isso significa a suposição de que pura e simplesmente e, portanto, a todo tempo o possuímos. Na medida em que efetivamente o realizamos, nós sabemos que somos os únicos aos quais ele há de ser atribuído. Nenhum outro pode com algum sentido, sequer uma vez, nos dizer 'eu'. A consciência do eu é a consciência do ato. A fórmula do pôr-se do eu tem em conta essa circunstância tanto quanto possível. Se, com efeito, isso de que tomamos consciência em virtude do nosso ato não fosse a efetividade do ato - como então tal consciência poderia ser chamada de autoconsciência?

o poder de convicção desse argumento é grande, porém apenas aparente. Uma consciência que é chamada a se efetuar, não pode se tornar efetiva somente através desse chamado. Ela já tem de estar presente e, aliás, em toda sua estrutura, [202] implícita ou potencialmente. A quem deveria chegar esse chamado, se a consciência se comportasse de outro modo? O que ali está presente, sem dúvida, tem de ser tal que permita aquela apropriação ativa que o chamado quer produzir. É possível também que uma atividade já seja inerente àquele que foi chamado. Ela pode ser adequada para explicar o caráter ativo da apropriação. Mas, ainda assim, a apropriação ativa permanece uma consequência possibilitada por aquela outra atividade. 0 ser-si (Selbstheit) do eu precederia toda apropriação. - Se a experiência da ipseidade (Selbstsein) compreende uma atividade, isto não significa, portanto, que egoidade (Ichheit) e atividade sejam idênticos. Algo similar se dava no caso da reflexão. Sua possibilidade também está fundada no eu, sem que, com isso, o eu seja explicado.

Existe ainda um outro argumento que fornece um peso maior à afirmação de que ipseidade é ato. Sua atividade tinha aparecido, anteriormente, como uma de suas possibilidades essenciais. Não se pode falar dessa maneira, se devia ser mostrado que é inerente a toda ipseidade essa exigência do ato e da autoapropriação ativa. Se a ipseidade está essencialmente sob uma exigência, então sua relação com o ato é originária a partir do próprio fundamento e é mais do que mera possibilidade. Que isto procede desse modo, foi a conhecida conviç̧ão de Fichte. De início, porém, ela não encontrou um lugar bem-definido na sua teoria da autoconsciência.

\section{O eu se põe como pondo a si mesmo}

Vimos que a primeira teoria de Fichte do pôr-se do eu evita, decerto, a circularidade da teoria da reflexão: ela não pressupõe o eu inteiro, enquanto quer explicá-lo a partir de um de seus momentos. No entanto, ela vai ao fundamento do saber de si do eu sem retornar ao próprio eu. Esse erro não permaneceu por muito tempo oculto a Fichte. Ele o corrigiu ao ampliar a primeira fórmula fundamental da doutrina da ciência. Desde o ano de 1797, ela diz: o eu põe-se pura e simplesmente como se pondo. ${ }^{14}$

Quem conhece as dificuldades da primeira formulação, vê imediatamente que esse novo complemento coloca ênfase no fato de que o resultado do pôr ativo é um saber. 0 'como' (als) visa o mesmo que o [203] 血' grego, a partícula da representação (Repräsentation). Todo visar (Meinen) visa algo em um modo determinado; todo saber 
expresso sabe algo de um algo determinado, o conhece, portanto, 'como' este algo. Quando Fichte enfaticamente explica que apenas a nova e completa fórmula atinge a essência do eu, ele diz com isso que o eu pode ser compreendido como um modo do saber: "A intuição da qual se trata aqui é um pôr-se como pondo (...), de modo algum, porém, um mero pôr." ${ }^{15}$ Autodeterminação por força própria é um fenômeno universal da natureza. A vida possui inclusive uma atividade que retorna a si mesma. ${ }^{16}$ Ambas não são 'eu'. Assim, a diferença específica entre natureza e liberdade se sustenta na única propriedade de que o pôr do eu se põe 'como' pondo e, com isso, é saber de si.

Fichte fundamenta a necessidade de ampliar sua fórmula com o mesmo argumento que ele tinha utilizado contra o círculo da teoria da reflexão: se o eu não fosse para si, então ele teria de ser para um outro. Neste caso, este outro seria, na verdade, o eu. Jamais chegar-se-ia a um eu da autodeterminação cognoscente (wissende Selbstbestimmung).

Essa consequência se impõe e a ampliação da fórmula fundamental era inevitável. Ela acarreta, porém, um novo problema. A partícula de representação 'como' indica uma relação triádica: Algo (1) representa algo (2) como algo (3). Ter-se-á de perguntar de que modo há de se localizar esses três momentos no eu que se põe.

A antiga fórmula já deixava margem suficiente para perguntas desse tipo. Só que ela não as impunha. Assim, é melhor começarmos recolocando essas novas questões em conexão com ela: de acordo com a antiga fórmula, o eu deve se pôr. Admitamos que a conhecida dificuldade não existisse e que, portanto, o resultado da produção do eu pudesse valer como um saber. De que espécie seria esse saber? Seria ele uma presença intuível do producente ou um pensamento da egoidade producente? o segundo caso está manifestamente excluído. Pois falta, ao mero pensamento do eu, aquilo que toda autoconsciência possui - a certeza da existência de si mesmo. Se o eu se pusesse apenas como conceito de si, então pertenceria à sua essência não poder ter nenhuma certeza [204] da própria existência. Cada eu se realizaria no pensamento da egoidade em geral, sem ser assegurado de um eu efetivo, muito menos de si mesmo. Friedrich Heinrich Jacobi manifestou a suspeita de que o eu de Fichte seria um fantasma. ${ }^{17} \mathrm{O}$ pensamento do mero caráter conceitual do produto do eu faria do eu como que um fantasma absoluto. Isso sugere tomar a posição do eu como uma intuição de si. Mas isso também traz suas dificuldades. Intuições sem conceitos são cegas. Também neste caso se revela quão amplamente essa proposição de Kant pode ser empregada. Se tomássemos o saber do eu somente como um olhar sobre si mesmo, estaríamos lhe trancafiando no porão de Auerbach. Como ele poderia sequer compreender que ele descobriu a si mesmo, se ele não pode também possuir uma compreensão de sua ipseidade - logo, um conceito de si mesmo? É a segunda variação da circularidade na teoria do eu como reflexão que proíbe interpretar o eu exclusivamente enquanto intuição de si mesmo.

Se existissem apenas essas duas possibilidades, de que o eu se ponha ou como conceito ou como intuição, de modo que tivéssemos de escolher dentre uma delas, optaríamos pelo paradoxo menor, considerando o eu pura e simplesmente como intuição de si. A fórmula ampliada, entretanto, nos liberta dessa necessidade: "o eu põe-se pura e simplesmente como se pondo." Afinal, ela inclui o fato de que o eu possui um saber daquilo que ele é. $\mathrm{O}$ eu conhece o pôr. Por isso, ele sabe de si que ele é ponente. $\mathrm{E}$ justamente isso que ele sabe é posto por ele. Portanto, é preciso admitir, desse modo, que pertence ao eu tanto um momento de caráter conceitual quanto outro de caráter intuitivo. Em virtude do primeiro o eu tem conhecimento de si segundo sua essência, em virtude do outro ele pode saber que ele é real enquanto aquele que põe. Dessa maneira, 
a autoconsciência é ao mesmo tempo intuição e conceito. "Esta é a especificidade deste sistema, mesmo diante do kantiano." ${ }^{18}$

Já no fundamento da primeira fórmula de Fichte se encontrava o insight (Einsicht) de que não se pode derivar a autoconsciência a partir de um de seus momentos. $O$ produto do pôr tem de emergir ao mesmo tempo que a efetuação da [205] produção. A fórmula ampliada dá especial ênfase à imediatez desse 'ao mesmo tempo', mas ela afirma que não há um saber de si do eu se a intuição e o conceito do eu não estão ligados entre si. Eles são ambos "cooriginários"19. Quando Fichte diz que o eu é "sujeito-objeto"20, ele quer realçar, com isso, essa imediatez reforçada da sua unidade consigo.

Parece que Fichte foi bem-sucedido agora ao fazer de um modo completo e inatacável o contraprojeto à teoria do eu como reflexão. 0 resultado da atividade do eu é um saber fechado em si mesmo, não somente um ricochete sobre si mesmo. Não obstante, exatamente a progressiva consciência de Fichte do problema que o levou à nova fórmula, lhe obriga a uma nova revisão da teoria. Ela vai ainda mais fundo que a primeira. Dois argumentos podem esclarecer a sua necessidade:

46 a) A força de produção do eu ponente tem de realizar mais, conforme a nova fórmula, do que conforme a primeira. Ela tem de produzir em um instante o ter-se do eu conjuntamente com um saber de si. Não podemos tornar claro como ela consegue fazêlo, pois todo saber já se encontra sob a duplicidade cujo esclarecimento está em questão. Mas o eu deve pôr-se 'como' si mesmo. Se ele é aquela força de produção, então ele teria de poder ver como se origina dele próprio a duplicidade de seu autoconhecimento. Assim, em conexão com as próprias reflexões de Fichte, vem à tona a surpreendente e em muitos pontos decisiva questão, se o eu, em última instância, está determinado por meio do discurso do 'pôr de si mesmo'.

b) O que acima se tornou visível a partir do lado do saber, deixa-se mostrar também do lado da produção. Seu produto é o saber enquanto unidade de uma intuição e de um conceito da atividade. Ora, se o saber está completamente determinado através destes dois momentos e se estes são produto de uma produção, - deve então também a produção ser o que é [206] sabido no produto? Que assim seja, a fórmula do pôr-se do eu certamente o exige, mas depois que ela foi desdobrada até sua segunda variante, faz-se necessário que ela própria seja posta em discussão.

Desse modo, forma-se um pensamento que faz preceder ao eu ativo um fundamento ativo, a partir do qual se explica a unidade cooriginária de seus momentos, mas que nele não vem à presença. Não este fundamento ativo, mas somente o seu resultado pode ser denominado 'eu', pois 'eu' significa ser-para-si. A condição da sua unidade, entretanto, não é o seu tema, mas somente sua origem. Um tal pensamento corresponderia aos dois argumentos que obrigam a introduzir uma diferença entre o eu-produto e o eu-atividade, uma diferença que até então não estava prevista por Fichte. Para além disso, esse pensamento teria ainda uma outra prerrogativa: em um eu que fosse pensado dessa maneira, seria possível produzir uma equivalência entre o momento do conceito e o momento da intuição. A saber, se o eu-objeto é a própria atividade originariamente producente, então no eu cognoscente (wissendes Ich) a primazia cabe à intuição, pois nela seria dada a força de produção. $O$ conceito apenas permitiria que a intuição possa ser sabida enquanto tal. No caso de um eu, no qual o euconceito e o eu-intuição são representações equivalentes de uma atividade, haveria a possibilidade de determinar a própria atividade intuitiva pelo caráter conceitual não somente como pensamento, mas no modo de seu ser-ativo. Essa possibilidade, porém, 
abre perspectivas favoráveis à fundamentação da filosofia prática. Afinal, a consciência moral é a experiência de um pensamento que tem como consequência um modo da atividade e, por conseguinte, é algo totalmente outro que o seu conhecimento.

\section{O eu é uma força na qual está inserido um olho}

49 Assim, pois, Fichte substituiu na doutrina da ciência de 1801 sua fórmula original por uma totalmente nova. Autoconsciência é, a partir de agora, "uma atividade, na qual um olho está inserido". Essa fórmula utiliza-se de uma metáfora quando fala do 'olho' do eu. Isso não significa que, com ela, Fichte encontra retiro na poesia especulativa. Ele simplesmente tenta comunicar um avançado insight, que não é [207] formulável com as palavras da linguagem que até então os povos e seus filósofos construíram.

50 A primeira fórmula de Fichte foi uma reação contra a teoria do eu como reflexão. A nova fórmula, a terceira, também só pode ser compreendida como uma reação - desta vez contra o próprio passado filosófico de Fichte. Ela desmente expressamente a interpretação que o pensamento fundamental de Fichte tinha encontrado na sua primeira doutrina. É preciso apenas observar que, conforme a primeira fórmula, o saber de si do eu estava 'posto', e que agora, porém, significa que ele está 'inserido' ${ }^{21}$. A voz passiva assumiu o lugar da voz ativa. Isso indica que à atividade, que através de um olho se tornou capaz de ver (sehend), é preciso pressupor ainda uma outra, em virtude da qual ela se tornou atividade que vê (sehende Tätigkeit). Com isso, ainda não designamos completamente o contraste com a primeira doutrina. Primeiramente, o uso da voz passiva teria como resultado apenas que o olho 'é' inserido na atividade. Não obstante, Fichte constrói o passivo, a partir de 1801, de modo estereotipado com 'estar' (sein) e não com 'ser' (werden) 22: um olho está inserido na atividade. Essa nuança acentua o sentido de sua nova fórmula. Ela enfatiza que a atividade só pode ser encontrada sempre em conjunto com o olho: se o olho é (wird) inserido, então a atividade precede a obtenção do olho; se o olho está (ist) inserido, então atividade e olho são conjuntamente uma essência. $O$ olho se relaciona à ação não como um adereço ao corpo, mas como o coração à vida. Com isso, Fichte se apoia em motivos que já se encontravam no fundamento da primeira forma de seu insight, mas que se tornaram visíveis especialmente no contexto da segunda fórmula: os momentos do eu não se deixam separar entre si. Em toda mediação no eu, a unidade de seus momentos está pressuposta; assim também a teoria tem de cuidar para que essa unidade não se esfacele em suas definições e deduções.

51 Na doutrina da ciência mais tardia, essa unidade dos momentos no eu é a base para um processo que Fichte já havia descrito antes como 'atividade recíproca'. Por um lado, o olho é o fundamento de um saber do fazer, o qual é apreendido e interpretado. Como tal, ele é o fundamento do conhecimento. Por outro lado, porém, o olho se enraíza no próprio fazer; mas não como um obstáculo, inserido como a obturação no dente ou mesmo um espinho na carne. Neste caso, a ação estaria obstruída por sua visão. $\mathrm{Na}$ verdade, porém, ele é ato clarividente [208], que é determinado positivamente por seu olho: o olho conduz o ato através do conceito. Por isso, o eu é fundamento do agir moral. A fórmula da atividade do olho pode, por isso, ser dita também assim: "força, na qual está inserido um olho, dela inseparável; força de um olho, este é o caráter do eu e da espiritualidade" 23 . 
52 Até agora a fórmula da atividade do olho foi apresentada como contraprojeto à primeira fórmula. De fato, ela foi configurada para eliminar as deficiências desta última. Mas essas deficiências só se tornaram evidentes quando a segunda fórmula estava desenvolvida, que por sua vez tinha reparado certas fraquezas da primeira. Portanto, o ganho trazido pela segunda fórmula tem de ser mantido na terceira. Precisamos agora considerar se e de que modo isso ocorre.

53 A primeira formulação de 1794 tinha dois membros. Ela designava uma atividade e seu produto. A terceira fórmula também nomeia apenas dois membros - atividade e olho. Mas estes são de tal modo compreendidos que a grande riqueza da segunda fórmula segue-se deles imediatamente. 0 'como' da representação, o que é peculiar à fórmula de 1797, é facilmente obtido a partir deles. É preciso apenas determinar ainda mais de perto o sentido do discurso sobre o 'estar-inserido'. Poder-se-ia pensar que esse olho está inserido no fazer tal como um olho de marfim na cabeça de mármore da estátua. Neste caso, a visão do olho se dirigiria, a partir do fazer, para fora e ao longe. Fichte, porém, quer dizer que o olho está inserido no fazer de tal forma que o olhar se dirige ao próprio fazer. 'Inserido' significa aqui ao mesmo tempo 'imerso adentro'. Assim, fazer e olho tornam-se um mundo para si. A atividade é clara através do olhar. Essa luz não penetra nela de fora e tampouco reluz a partir dela. A atividade do olho é um mundo de luz com limites impenetráveis. Por ser assim, fracassa todo modelo espacial e, com ele, a linguagem que foi construída no mundo do espaço.

54 Somente quando pensamos a atividade do olho deste modo torna-se ela um pensamento do eu e do seu ser-para-si. Mas então fica óbvio que o olho, que divisa a atividade, tem ao mesmo tempo de ver a si mesmo [209]. Pois a atividade é essencialmente atividade do olho; ela pode ser vista, por conseguinte, apenas simultanemente com o olho. $O$ pensamento de um olhar que capta a si mesmo fascinou Fichte invariavelmente a partir de 1801 e durante os últimos treze anos de sua vida. Ele procurou apreendê-lo cada vez mais precisamente como o problema da filosofia e desdobrá-lo em suas mais amplas consequências. Um testemunho disso pode ser a seguinte passagem de um manuscrito ainda inédito, provavelmente anotado no verão de $1812^{24}$ : "18 de agosto. Férias. Em um sonho, de modo luminoso revelou-se a mim uma tarefa. $O$ ver é um olho que vê a si mesmo (...) Olho que vê a si = reflexão de uma vida, de um revelar a si, que (permanece) justamente em si mesmo e em sua faticidade". A autorrelação do eu é o ser-para-si de um saber que é manifesto para si mesmo; ao mesmo tempo, porém, é um fato (Faktum) que explica tudo a partir de si, só não explica sua própria existência. Ele se conserva nessa existência, sem poder penetrá-la com sua luz. Ora, se o olho deve poder se conhecer, ser efetivamente 'para-si', então também seu olhar tem de poder ser da mesma espécie que o "pôr" da segunda fórmula: o olho tem de ver a atividade do olhar como tal. Portanto, é preciso poder distinguir em seu olhar um momento da intuição e um momento do conceito. O olhar é (a) a atividade, na medida em que ela é (b) presentemente intuível e, com isso, experimentada como efetiva. Além disso, ele é (c) a atividade pensada na (d) determinidade de seu conceito. Pode-se discutir se essa última distinção é imprescindível ou se já é suficiente indicar três momentos. Fichte enumera sempre os quatro momentos mencionados. Somente após essa interpretação ampliada da fórmula é possível pensar uma determinação recíproca no eu, de tal modo que ele seja originariamente autoconsciência tanto teórica quanto prática. 

ele pode ser completamente interno ao fazer e ser sua autorrelação cognoscente (wissender Selbstbezug) - só assim ele pode ser compreendido como autoconsciência. Combinada com a quadruplicidade dos momentos do pôr como pôr, essa terceira fórmula de Fichte parece agora impecável.

56 [210] Entretanto, exatamente nessa combinação oculta-se outra vez um novo problema. O discurso sobre o olhar que vê a si mesmo e sempre já é esse ver, preserva, decerto, a unidade originária dos momentos do eu. Ela consiste na autorrelação do eu, tal como a primeira fórmula a faz passar por seu caráter mais essencial. Contudo, é ela capaz de tornar clara uma tal autorrelação? Ela precisaria fazê-lo mediante os quatro elementos que estão contidos na consciência do olhar como olhar. Ora, esses momentos são certamente imprescindíveis. Mas são eles também suficientes para explicar a autorrelação da consciência? Isso, de modo algum, parece ser o caso. Um conceito que determina uma realidade dada (Gegebenheit) pode, naturalmente, definir de forma explícita aquilo que está dado intuitivamente. Porém, disso não resulta de modo algum uma autorrelação da intuição. Ao contrário, o conceito pressupõe seu sujeito, que o pensa e que com ele conceitua a intuição. Por causa do conceito, esse sujeito jamais poderá ser o próprio dado na intuição. Mesmo um conceito, evidentemente, não é determinado com referência a si mesmo através da intuição que se pode associar a ele. Isso é trivial. Que surja uma diferença entre a realidade dada e a consciência do 'como', também era apenas a pressuposição para uma autorrelação no eu, de modo algum já era a definição do próprio eu. É mediante ela, mas não como um caso qualquer dela, que há autoconsciência.

Ora, poder-se-ia pensar que é suficiente denominar o olhar do olho que se dirige a si mesmo como um caso característico, no qual a relação de intuição e conceito torna-se uma autorrelação. Mas isso não basta. É preciso mostrar também como a autorrelação da atividade do olho se torna, nesse caso, atuante na intuição e no conceito. Não só o conteúdo, a própria relação tem de apresentar a particularidade da autorrelação. Se fosse diferente, então os meios, em virtude dos quais a atividade do olho sabe de si, permaneceriam meios totalmente arbitrários, que não seriam por ela possuídos nem incluídos em sua estrutura fechada (geschlossenen Zusammenhang). Disso resultaria uma situação que Fichte procura evitar mais que qualquer outra: o eu não seria para si, mas somente para um eu superior. Mas, então, a autoconsciência em geral não seria possível. Fichte pensa satisfazer a essa necessidade quando acrescenta à quadruplicidade um quinto momento: (e) a referência recíproca imediata de intuição e conceito. Se algum estado de coisas qualquer [211] é compreendido por um sujeito do conhecimento, é sua intuição, então, que ele esclarece por seu conceito, ou é seu conceito que ele preenche com uma intuição. Nunca o conceito é referido à intuição a partir de si próprio, e vice-versa. Mas isso vale para a autoconsciência: um pensamento já é sempre realidade e se apreende como tal, e uma intuição da realidade é, sem mediação, conhecimento intuitivo (unvermittelt einsichtige Kenntnis). Essa particularidade, que decide tudo, qualifica intuição e conceito do eu neles mesmos. Como, porém, intuição e conceito tinham sido introduzidos como caracteres separados da autoconsciência, o caráter da egoidade próprio a eles também tem de ser contado como um momento particular. Assim, a autoconsciência será pensada doravante como síntese de cinco membros ${ }^{25}$.

Revista de Estud(i)os sobre Fichte, 22 | 2021 
É por via negationis, com a determinação pela exclusão do oposto, que esse pensamento também trabalha: conceito e intuição devem estar em uma relação oposta à relação comum. A essência do eu deve ser compreendida através desse caminho. De fato, desse modo também se é remetido à inconfundível particularidade da essência do eu. Mas é ele determinado de tal modo que sua constituição interna esteja completamente compreendida?

Tem-se de responder negativamente a essa pergunta. Se compreendêssemos a essência do eu, teria de ser possível reconstruir a conexão do todo partindo de um dos seus momentos. Desse modo, ter-se-ia de poder ver, por exemplo, como na consciência do conceito o 'eu' desdobra um saber de si mesmo. Mas isso é impossível. Admita-se que é conhecido um conceito; além disso, que se sabe que esse conceito determina uma intuição e que essa intuição também está dada. $O$ saber, que possui o conceito, seria, então, ainda sempre incapaz de constatar que ele apreende a si na realidade dada (Gegebenheit) da própria intuição - a não ser que de alguma outra maneira ele já tivesse travado um conhecimento consigo anteriormente. Como há de se excluir isso no caso da autoconsciência, a expectativa de que o eu deva ser compreendido a partir do seu caráter conceitual não se realiza. Aqui, em um terreno totalmente outro, o círculo da teoria da reflexão [212] do eu na sua segunda variante faz-se válido: se o eu não sabe anteriormente de si, ele nunca pode chegar a um saber de si.

A essa objeção Fichte não deu a mesma atenção que à primeira. Esta tinha mostrado que a teoria do eu como reflexão pressupõe ilicitamente todo o eu antes que seja efetuado o ato da reflexão, em virtude do qual, aliás, esse eu deve se realizar. Fichte livrou sua teoria dessa objeção. Mas a segunda objeção não se dirige mais ao fato de que em todos os casos do discurso sobre o eu já esteja presente uma autorrelação. Ela mira o fato de que, em toda autorrelação, o eu tem de poder se conhecer como eu. Parece que um tal conhecimento só pode ser sempre um reconhecer (Wiedererkennen). Nisto, então, sempre se instala um círculo. E é completamente possível lançar tal objeção também àquelas teorias que supriram as outras deficiências da teoria da reflexão.

Através da sua segunda fórmula, Fichte já tomou um caminho com o qual se desvia das ciladas desse círculo. Mas sua atenção não estava dirigida a elas. Ela tinha sido requerida pela tarefa de pensar o eu sem a pressuposição de um outro sujeito superior. Isso permaneceu assim. Na sua obra, não encontramos em nenhum lugar ponderações cujo propósito seja querer fazer justiça completamente à segunda objeção. Notar isso significa marcar um limite da contribuição de Fichte para a teoria da autoconsciência.

22 No entanto, é possível formular com os meios de Fichte uma solução para o problema. Essa solução, além disso, abre interessantes perspectivas teóricas. Seu começo já foi feito: a saber, foi mostrado que a relação recíproca de eu-conceito e eu-intuição tem de ser atribuída sem mediações à autoconsciência. Caso se comece a construí-la a partir de um de seus membros, então sua reflexividade nunca é alcançada, o para-si da autoconsciência permanece inconcebível. Disso é possível concluir facilmente que a relação de intuição e conceito tem de possuir um caráter de saber. E, de fato, parece ser ela exatamente aquilo em virtude do que a autoconsciência em geral é cognoscente (wissend). Se ela não fosse aquilo que se pode denominar o núcleo cognoscente (wissenden Kern) do eu - como, então, seria possível compreender a autoconsciência em geral como saber e, aliás, como um saber imediato? Ter-se-ia de dizer, então, que nosso saber de nós é algo deduzido, de tal modo que o eu não estaria dado a si mesmo, mas [213] somente teria conhecimento de si. Esse caminho é logicamente possível, mas está 
em manifesto conflito com o fenômeno do eu, fenômeno que é a pressuposição imediata e certa de todo saber deduzido.

Ora, é bem paradoxal admitir um estado do saber que é sem sujeito. Parece ser claro que só se pode falar do saber ali onde também pode ser designado aquele que possui tal saber. Mas se o eu do próprio sujeito já é um saber, essa proposição supostamente evidente não pode valer sem uma delimitação. Isto é, se todo saber tivesse efetivamente um sujeito, então o próprio sujeito não poderia ser um saber; do contrário, ter-se-ia de admitir também um sujeito desse sujeito e recair no regresso ao infinito, que Fichte tanto temeu. O pensamento do eu se afundaria no insondável. Diante disso, é preferível o paradoxo do saber sem sujeito. A rigor, também não é estranho que ali onde se chega ao ponto central de orientação de todo saber, talvez até mesmo em seu fundamento, não se possa mais encontrar as familiares estruturas com as quais nós descrevemos adequadamente $o$ ato do conhecimento de estados de coisa isolados ou compreensões derivadas. Quem se empenha em uma teoria filosófica do eu tem de considerar a possibilidade de que, no retorno aos princípios, há de se renunciar a formas mundanas de interpretação. Se ele considera um tal pensamento absurdo, então nunca poderá alcançar o fenômeno 'eu' e promover os problemas que este coloca como tarefa. Ao invés de se orientar por eles, terá de se orientar por suas pré-concepções.

Isso, sem dúvida, não é uma apologia de qualquer afirmação que atribui ao eu o saber em um sentido paradoxal - tampouco apologia da afirmação de Fichte. Já se tem de indicar o lugar determinado que esse modo do saber ocupa. Em Fichte, ele é a relação recíproca de conceito e intuição em uma atividade que essencialmente sabe de si. Para a designação desse saber ele dispõe de três palavras: ele o chama o 'como' (Als), o 'si' (Sich) ou o 'através' (Durch) do saber. Assim, apenas o saber imediato do eu torna possível o 'como' do conceito. Afinal, em virtude dele estão no eu - portanto, não em referência a um eu - intuição e conceito em relação entre $\mathrm{si}^{26}$. Essa relação também pode ser designada como o 'si' (Sich) da egoidade ${ }^{27}$. [214] Pois em virtude dele o eu está em uma autorrelação que é autossuficiente e que não tem necessidade de nenhum ponto de vista exterior a ela. Pode-se mesmo dizer que, em tal saber, experiência de existência (intuição) e consciência do 'como' (conceito) do eu dependem reciprocamente uma da outra, de modo que cada uma é pela outra, todo saber, porém, é "o através (Durch) absoluto dos dois, a imagem da sua conexão absoluta e viva." ${ }^{28} \mathrm{Em}$ todo caso, esse saber é, para Fichte, 'unidade, luz', e, aliás, uma luz "qualitativamente absoluta, a ser somente efetuada, de modo algum conceituada" 29 . Em formulações como esta, Fichte se mantém na posição de que o eu é 'intuição intelectual'. Essa tese já possuía, na primeira doutrina da ciência, uma importante posição. Ela tinha despertado bastante discórdia. Agora ela adquiriu uma univocidade maior: antes não tinha ainda ficado claro se a intuição intelectual é somente nosso saber do eu ou é o próprio eu. Ambos se deixavam afirmar ao mesmo tempo, e uma conexão objetiva entre ambos tem também, evidentemente, de ser assumida. Agora, porém, não existe mais nenhuma dúvida de que o termo visa sobretudo a constituição interna do eu e seu modo de saber.

Antes que venham à tona advertências contra a posição de Fichte, é preciso conceder que ela é algo totalmente diferente de uma tese arbitrária, que oculta uma dificuldade não resolvida. Ela se deu em uma sucessão de diversos estágios da reflexão. Cada um deles foi uma revisão do anterior. Cada um corrigiu tanto representações usuais da essência do eu como também concepções que vão mais fundo, mas sempre ainda insuficientes. Passo a passo foi trazida à luz a autêntica e admirável constituição da 
autoconsciência. Esse esclarecimento, contudo, veio acompanhado de um obscurecimento: enquanto a constituição do saber-eu (Ich-Wissen) foi obtida sempre mais claramente, concebê-la revelou-se também sempre mais difícil. o caminho pelo qual teve de ser descartada uma imagem do eu depois da outra torna-se finalmente uma parte essencial do conhecimento do eu. Pois as proposições nas quais Fichte, por fim, fala do eu são somente ainda a expressão paradoxal do reconhecimento de que o eu se furta à construção por conceitos. [215] Com isso, ainda não está ganho nenhum critério suficiente de um discurso adequado sobre o eu. Afinal, poder-se-ia supor que a série de expressões paradoxais, que sobrepujam uma à outra, ainda não está esgotada. Ela poderia, até mesmo, ser infinita. Neste caso, o fenômeno 'eu' faria troça de todos esforços por uma definição. Poder-se-ia, então, perguntar se ele mesmo não inclui uma infinitude de significado ou se somente a desproporção entre o sujeito do conhecimento e o conhecimento não é uma desproporção infinita. Fichte, não obstante, possui um outro critério: a autoconsciência está adequadamente determinada em expressões paradoxais se elas permitem interpretar o sistema do saber derivado. O eu é sujeito do conhecimento. Nele têm de se encontrar as condições que instituem entre si a conexão interna de todo conhecer. Aquele que consegue desenvolver essa conexão também tem de ter dito algo acertado sobre o eu, mesmo se ele não pode dar ao seu discurso nem a forma da dedução, nem a forma da descrição de um estado de coisas unívoco. Assim, o sistema da doutrina da ciência é ao mesmo tempo a tentativa de justificar sua fundamentação.

Por um bom motivo, entretanto, Fichte tomou sua teoria por insuficiente. A unidade do eu não seria possível se os momentos da sua essência não fossem 'internos', dispostos inseparavelmente juntos e determinados um pelo outro. Fichte, contudo, jamais conseguiu tornar a teoria dessa disposição unívoca. Mesmo as exposições tardias da doutrina da ciência contêm muitas indefinições. O plano de uma publicação da nova exposição da doutrina da ciência, já anunciada em 1801, sempre teve de ser postergado, até que, finalmente, caiu em esquecimento.

Abstraindo das deficiências, de que o próprio Fichte já era consciente, temos de constatar que sua doutrina do eu faz um uso por demais natural de distinções terminológicas que são apenas extraídas da filosofia kantiana. Assim, sente-se falta de análises da significação de 'intuição' e 'conceito', essa oposição fundamental que, em 1796, entrou na fórmula da autoconsciência. Se utilizamos os métodos desenvolvidos por Hegel, pela fenomenologia ou pela análise lógica, em todo caso podemos esperar esclarecimentos sobre as condições sob as quais tais conceitos podem ser empregados esclarecimentos para além daquilo que [216] Fichte sabe dizer. Dessa maneira, mais luz será lançada nessa estrutura, cuja descoberta e desenvolvimento é mérito permanente de Fichte.

Fichte sempre esteve convencido de que, no fundo, só há de se atribuir à doutrina da ciência um único insight. Sua doutrina, frequentemente apodítica, intratável e impetuosa, deveria forçar-nos ao ponto de vista possibilitado por esse insight e mostrar que é possível sustentar-se nele na construção de um sistema do saber filosófico. Daí em boa parte tratar-se, para Fichte, de tornar o pensamento fundamental tão claro quanto possível - tão claro quanto tinha se tornado ao próprio filósofo. Pareceu-lhe que todo aquele que o apreendeu uma vez, dedicar-lhe-á todos esforços da sua reflexão também que lhe proporcionará uma certeza da primazia e dignidade da liberdade que sabe de si, certeza que não pode mais ser abalada. Tal certeza não traz, porém, o 
repouso do conhecimento seguro. Ela apenas desperta um intensificado desejo de encontrar o fundamento de uma teoria que sempre permanece suscetível de melhoramento. Pois o mais próximo, nós próprios, o saber-eu (Ich-Wissen), é o que há de mais obscuro ao nosso conhecimento discursivo. Fichte assentou essa experiência da sua vida em um pequeno manuscrito. Ele está acima de toda suspeita de uma autoapresentação dissimulada, suspeita que bem poderia atingir muitas manifestações em suas preleções. Esse manuscrito é uma sequência de três sonetos - surgidos por volta de 1812 e não destinados à publicação. Sob o signo da doutrina da ciência, eles equivalem a uma biografia filosófica. No segundo soneto, Fichte pergunta o que deu a ele a força de, na confusão do curso do mundo e nas crises da sua vida exterior, seguir firme o caminho da sua filosofia da liberdade. A resposta diz:

É assim por ter eu mesmo quieto adentro olhado

No olhar de Urânia a flama-luz a si incender

Profunda e azul e quieta em pura claridade.

É assim que tal olhar profundo em mim pousado

Reside e em meu Ser é. Por isso vê em meu ver

E vive em meu viver - a eterna Unidade ${ }^{30},{ }^{31}$.

[217] $\mathrm{O}$ insight da essência da egoidade indica à doutrina da ciência o seu caminho. A essência da egoidade é a atividade do olho: conceituá-la foi a tarefa que 'com fulgor revelou-se' ao Fichte sonhador naquele ano. Ao falar dela, instituem-se, novamente, metáforas obscuras, desta vez em um poema cujo alcance metafórico, de resto, é pequeno e convencional e, assim, fácil de ser penetrado. 0 olho de Urânia, a musa da astronomia e, portanto, do conhecimento natural, é o sujeito do conhecimento finito. Fichte enxerga nele aquele outro ver que não se dirige ao mundo, mas difunde uma luz no próprio olho - uma luz que não ilumina nada, mas é clara para si mesma. Nós não podemos acender essa luz. Pois ali onde estamos, ela já flameja. Assim, temos de estar 'tranquilos' quando ela brilha: no entanto, não podemos vê-la se somos passivos. Afinal, sem nosso ver, fora dele, ela não se acha. Não é ao ser produzida por nós que a encontramos, mas somente no efetuar do 'eu'. Por isso pode-se dizer: essa 'flama-luz' é 'quieta adentro vista' no sujeito do conhecimento.

O soneto fala, na linguagem da doutrina da ciência tardia, sobre o insight que conduziu Fichte ao seu caminho. Nós sabemos que Fichte, num primeiro momento, o expôs de modo totalmente outro; mas isso não exclui que, já naquele momento, Fichte tinha a mesma coisa diante dos olhos, embora sua interpretação ainda não fizesse justiça a ela. $\mathrm{O}$ 'incondicionado no eu', ao qual conduzem os primeiros textos teóricos de Fichte ${ }^{32}$, não é, olhando retrospectivamente depois de vinte anos, nada mais que a 'força na qual está inserido um olho', o conceito-chave da doutrina da ciência tardia.

Inicialmente, Fichte pensava que a autossuficiência desse saber ativo só pode ser interpretada como o ato da liberdade. Depois, porém, ele se convenceu de que há um fazer que já é sempre cognoscente (wissend) [218]. Desse modo, ele não pode se tornar cognoscente (wissend) por si. Disso se segue, pois, que na regressão aos fundamentos ele é somente o último estado de coisas que pode ser dado ao nosso conhecimento - não, contudo, o último tema do nosso questionar. 'Eu' não é nem fundamento de si mesmo, nem dispensa qualquer fundação ulterior. Temos de distinguir nele momentos que, não obstante, estão em uma conexão que é indissolúvel. Precisamos perguntar, portanto, pela origem dessa conexão. 


\section{0 eu é fenômeno}

72 A doutrina da ciência tardia de Fichte apreendeu o pensamento da impensável fundação da ipseidade em um 'Absoluto'. Facilmente pode parecer que esse pensamento está em contradição com o conteúdo essencial da primeira teoria. Esta queria ser um chamado à liberdade e fonte da conviç̧ão de que o homem poderia depender apenas de si mesmo. Ter revelado a liberdade foi, para Fichte, o mérito da filosofia crítica. Até o fim ele foi grato ao seu professor Kant por tê-lo libertado do jugo da sua filosofia determinista de juventude. Fundamento da liberdade - isso não é uma contradição em si?

73 Muitos assim o pensaram. Eles entenderam o percurso de Fichte como acomodação e renúncia da coerência de seu tempo áureo. De fato, Fichte quase não teria se decidido a interpretar a liberdade ela própria como consequência de algo outro, se uma nova experiência de vida não o tivesse aberto a essa conviç̧ão. O conflito em torno da censura do ateísmo e sobretudo a carta que ele, em situação difícil, recebeu de Jacobi, desencadearam nele um movimento que acelerou a mudança de sua doutrina. Sob outras condições, não se sabe se e quando ela teria se transformado. Uma filosofia convincente depende das experiências que ela ilumina, logo, também do efeito e do eco que ela encontra em outros. Não obstante, Fichte não iludiu nem a si nem a seus ouvintes quando posteriormente assegurou, tão frequentemente quanto possível, que a doutrina da ciência sempre permaneceu, no fundo, a mesma. Todas mudanças que ela experimentou apenas elevaram a clareza sobre a peculiaridade e a coerência do seu insight original.

Não se pode confundir a tese do fundamento da liberdade com a afirmação de que a liberdade seria imaginária e todo agir seria [219] somente guiado por impulsos e preconceitos. O fundamento fichteano da liberdade é outro que a causa exterior de ações, que, neste caso, apenas supostamente são livres. Na doutrina da ciência, a própria liberdade é entendida a partir de uma possibilidade não disponível a ela. Esse fundamento é assim, inversamente, a condição da autonomia dela. Ele tampouco é uma meta que paira diante da consciência, a fim de que esta, em liberdade, sirva a ele. Neste caso, a liberdade seria pensada - quão sutil o seja - como um meio. No entanto, a liberdade é autodeterminação e não ocorre em vista de um outro. E tal como a existência da liberdade, a unidade do eu também não pode ser concebida nem causal nem teleologicamente. Nem algo natural em nós, nem algo espiritual fora de nós pode fundar nossa existência racional. Nosso próprio ser, o saber simples e, contudo, enigmático 'eu' vem de um fundamento que não impede, mas possibilita a liberdade. Esse fundamento institui a autorrelação, na medida em que ele deixa a força, que essencialmente vê (sehend), ser. É possível, até mesmo necessário, colocar à liberdade perguntas que ela não consegue responder, sem indicar à filosofia um ponto de vista exterior à liberdade. Com essa tese, Fichte se defendeu contra a filosofia do sentimento e a filosofia da natureza, que foram seus principais adversários. Assim como sua primeira doutrina não é o testemunho da presunçosa vaidade do homem, tampouco é sua teoria tardia uma renúncia da liberdade.

Kant ensinara que um tal fundamento seria inconcebível, que a pergunta por ele é 'extravagante'. Sem dúvida, ele tinha representações de um tal fundamento que não são unificáveis com aquelas de Fichte. Com a proibição de perguntar pelo fundamento, ele pensava em uma classe de substâncias particulares que têm a propriedade incomum de 
deixar principiar séries de causas a partir de si. Para a ontologia que está em funcionamento neste caso, trata-se antes de uma afirmação baseada na Philosophia Naturalis de Newton do que na constituição interna da ipseidade, que ela, porém, ainda não pode tematizar. Para Fichte, 'substância' não é um nome adequado para a realidade 'eu', como tampouco para sua condição, que tem de ser tomada como condição de uma autorrelação. Há, contudo, uma boa razão para se pensar que atrás da força do olho da ipseidade o pensamento só tem alcance em um movimento vazio. Não é ela própria, pois, um caso limite para a capacidade de interpretação da linguagem de nosso conhecimento? Exatamente nessa compreensão a doutrina de Fichte se aproximaria muito de uma experiência do mundo moderno.

[220] Fichte, todavia, estava convencido de que a teoria pode tornar inteligível o fundamento do eu: ipseidade é manifestação de Deus. Como se, agora, Fichte atribuísse à liberdade uma causa da mesma maneira que Kant tinha em mente, e que não concorda propriamente com o insight de Fichte. Sua interpretação não é, porém, tão disparatada. Com o auxílio do conceito de Deus, Fichte quer tornar compreensível exatamente a essência do eu. Isso se dá do seguinte modo: a autoconsciência é a unidade interna a partir do fundamento não disponível e impensável. Ao mesmo tempo, ela é automanifestação (Sicherscheinen). Ela tem a si como si e precisa, na efetuação da sua atividade, adquirir outro saber sobre si. À ipseidade também pertence, enfim, a doutrina da ciência. Ora, essa ciência de si do eu tem como seu resultado que a ipseidade é unidade a partir de um fundamento não disponível. Portanto, é preciso dizer que também esse saber surge ainda da essência da ipseidade e entra em cena quando a ipseidade se perfaz. Mas então é possível pensar a ipseidade como manifestação. Mesmo anteriormente ela era manifestação, mas de si mesma; agora, ela é manifestação daquilo que, previamente a todo saber, funda sua possibilidade. Ficou claro que não é possível captar (einsehen) diretamente este Um. Mas é possível, pois, compreendê-lo a partir do seu efeito. Ele deixa vir a ser a ipseidade, que é essencialmente manifestação, para se tornar manifesto a si como o insondável. Assim, ele se manifesta finalmente no eu, como aquele que se manifesta (das sich Manifestierende) $)^{33}$. E justamente isso é o que visamos quando falamos de um Deus vivo ${ }^{34}$.

[221] Vê-se que Deus e eu nessa teoria não estão exteriormente ligados entre si. Sobretudo a doutrina da ciência de 1804 tenta mediá-los em direção a uma docta ignorantia da essência de Deus. Mesmo quem não quer segui-la, pode se admirar do seu sentido profundo e da sua coerência. Ela merece uma ampla interpretação.

\section{Apontamentos para o desenvolvimento histórico}

78 Até aqui nossas reflexões seguiram o encadeamento temático. O conceito do eu de Fichte foi desenvolvido sem referência ao sistema e aos problemas filológicos de uma Fichteforschung. Ao mesmo tempo, porém, também devia ser fundada uma tese histórica: aquela da unidade no trajeto da doutrina da ciência e da coerência na sucessão das três fórmulas sobre a essência da autoconsciência. É recomendável apoiá-la pelo menos com algumas referências à história do desenvolvimento de Fichte. Elas devem mostrar que essa tese de uma história detalhada dos motivos das mudanças em sua obra não seria refutada, mas confirmada. Elas fornecem também a oportunidade para precisar o sentido histórico de nossa reconstrução. 
79 a. No soneto de 1812, o próprio Fichte compreendeu seu percurso filosófico a partir de um insight originário. Mas aqui também ele não diz que teria conceituado esse insight desde o princípio em sua particularidade, importância e consequências. As duas coisas correspondem ao que realmente ocorreu. Só mais tarde Fichte alcançou a interpretação apropriada de seu insight. E mesmo da sua autêntica significação ele só tomou consciência alguns anos depois de seu surgimento. Isso se deu, no mais tardar, no ano de 1797, quando da escrita da 'Segunda introdução' e do 'Ensaio de uma nova exposição da doutrina da ciência'. Presumivelmente, porém, eles são somente uma reprodução da exposição corrigida da doutrina da ciência, que Fichte lecionava desde 1796 e da qual não possuímos até agora nem o manuscrito nem as cópias dos alunos ${ }^{35}$. Nesses textos, vem à luz de um modo claro a consciência de Fichte da circularidade da teoria da reflexão do eu e da sua própria teoria como uma reação a ela ${ }^{36}$. Clássicas são, então, [222] as colocações na Introdução à Doutrina da Ciência de $1798^{37}$. Embora só tenham sido transmitidas pela cópia de alunos, elas se encontram, todavia, em um alto patamar da crítica consciente de toda filosofia anterior sobre a autoconsciência.

80 A doutrina da ciência de 1794 não dispõe dessa clareza. De acordo com ela, o eu põe pura e simplesmente a si mesmo. Isso inclui o fato de que se pode afirmar a unidade imediata de seus momentos. Inicialmente, no entanto, Fichte não colocou uma ênfase nessa unidade. Antes, o sistema de 1794 explica o ser-para-si do eu - que, porém, é uma consequência direta do seu pôr-se - a partir de um dualismo: da oposição de uma atividade que vai ao infinito e de uma outra atividade que é oposta a ela. Essa teoria se tornou a vítima da incansável polêmica de Hegel. Mas ela era o mais passageiro e fugaz na autocompreensão de Fichte. Já na exposição de 1797 ela desapareceu. A partir dali, Fichte definiu o ato do pôr absoluto exatamente a partir daquilo que se segue dele. Pôrse significa: ser ao mesmo tempo, sem nenhuma mediação, sujeito e objeto ${ }^{38}$. Nesse sentido, ele pode significar: 'pôr ou sujeito-objeto', um termo que foi utilizado por Fichte apenas no ano de $1795^{39}$. Só um pouco mais tarde ele se tornou expressão para uma unidade imediata no eu.

81 É possível mostrar que o próprio Fichte, exatamente nesse ponto, conhecia bem as obscuridades da 'Grundlage'. Em 1802 ele deixou vir a lume uma nova edição da sua primeira obra principal, apenas ampliada por alguns adendos e notas de rodapé. A mais importante é agregada à cifra 10 do primeiro parágrafo. Ali, Fichte tinha tratado do serpara-si essencial do eu. No percurso ulterior da doutrina da ciência, ficou evidente que esse ser-para-si é considerado geneticamente, de modo algum imediatamente. A atividade do pôr o realiza somente mediante um oposto a ela. A observação abstrai disso e comenta: o eu é sujeito-objeto sem mediação. Com isso, Fichte dá uma importância a um trecho da sua obra que, anteriormente e no [223] contexto originário, ele não tinha. Havia razão para tomar isso como necessário.

b. Desse modo, portanto, o insight de Fichte se realizou sob condições que não são idênticas aos argumentos que, mais tarde, serviram para a sua fundação. A luz no olho de Urânia não brilhou em decorrência da crítica da teoria do eu como reflexão. E com isso, também ainda não está esclarecida, em nossas reflexões, a história da gênese de seu insight. Ela ainda não foi sequer uma vez tocada. Aqui, acerca desse importante tema, podemos somente notar que a ideia da doutrina da ciência emergiu, provavelmente, a partir da combinação de três problemas: depois do sucesso da sua 'Crítica de toda revelação', Fichte recebeu ofertas muito honrosas para escrever resenhas na Gazeta Literária Geral (Allgemeine Literatur-Zeitung). Essa tarefa o obrigou a se 
colocar, na filosofia teórica, à altura da discussão da época e a tomar nela uma posição inequívoca. No espaço de meio ano, ele trabalhou nela intensamente e a fundou aproximadamente assim: (1) pode-se escapar das objeções céticas à filosofia kantiana, se atentamos para o fato de que a autoconsciência não é substância, portanto, também não é substância incognoscível, mas absolutamente saber e, aliás, saber incondicionado. ${ }^{40}$ (2) A filosofia moral, que tem de fornecer uma prova da realidade de uma razão prática, só pode dá-la sob a pressuposição de um incondicionado na consciência. A refutação da sképsis teórica tem, portanto, de se servir dos mesmos meios que a refutação da sképsis nos assuntos morais ${ }^{41}$. (3) A decisiva tentativa da época de apreender a doutrina de Kant como sistema, a Filosofia Elementar de Reinhold, é uma sequência de sofismas. Ela não pode ser nada mais que isso, já que entende a consciência somente como a relação de diferentes momentos entre si. Na tentativa de construir uma doutrina das categorias do pensamento puro, revela-se, porém, que: uma Filosofia Elementar só é então possível quando tudo em nosso espírito 'se conecta em uma cadeia'. A dedução tem de poder se apoiar em uma unidade suprema. Fica claro que se tem de buscá-la na incondicionalidade do eu. Mas esta não é unidade, mesmo se ela é apenas a última e insuperável evidência de uma relação. Assim, o eu tem de [224] ser pensado como o contrário de uma relação daquilo que subsiste (Bestehende). Eu é ato incondicionado.

83 Está conservado, para nós, o manuscrito no qual a gênese do insight originário de Fichte pode ser acompanhado tão precisamente como a de nenhum outro pensamento fundamental da filosofia. Kabitz já publicou anteriormente pequenos excertos dele ${ }^{42}$; sua publicação na edição crítica sob o título 'Algumas meditações sobre a Filosofia Elementar' é iminente.

84 A primeira forma da doutrina da ciência de Fichte, portanto, resultou da apropriação crítica de Reinhold. Quem conhece as meditações de 1793/4 ainda vê, nas páginas da 'Grundlage' do princípio do verão de 1794, transparecer a estrutura da obra de Reinhold. A crítica às suas fraquezas e a pergunta pela fundação de um sistema no espírito kantiano levaram Fichte ao pensamento de um eu que se põe pura e simplesmente. Portanto, esse pensamento não foi, mesmo no princípio, um golpe de gênio, mas resultado da tentativa de chegar a uma solução para as dificuldades teóricas. Mas naquele momento, ele ainda permaneceu totalmente subordinado à tarefa de superar Reinhold, defender com isso Kant contra Schulze e, assim, assegurar ao mesmo tempo o primado da razão prática. Todas determinações que são atribuídas ao 'eu absoluto' são entendidas a partir disso. Fichte ainda não pôde, livre e independentemente de toda referência à colocação da pergunta da época, ter em vista o conteúdo do insight que ele obteve nesse percurso. Seus estudantes e colegas, com os quais Fichte filosofou diariamente em Iena, cuidaram para que isso logo ocorresse. Mas ele tinha se tornado o que se esperava dele, que ele continuasse carregando a luz da filosofia crítica e, ao mesmo tempo, se tornasse o filósofo primeiro da universidade mundial de sua época. Vivo interesse e crítica apaixonada o rodeavam. Isso também teria impelido alguém que estivesse menos determinado pela coerência e clareza do que ele. Assim, logo se deu que a concepção de sistema de Fichte se desprendeu totalmente dos modelos que estavam dados a ele primeiramente por Reinhold. Apenas o conceito do eu, o método no desenvolvimento do sistema (não de sua exposição) e muitas compreensões da estrutura da vida subjetiva foram conservados. Eles entraram na nova interpretação 
[225] da ideia de sistema de Fichte. Ela nos foi transmitida na doutrina da ciência de 1798.

Vimos que o insight originário de Fichte abre uma nova época da reflexão sobre fenômenos da autoconsciência. Sua gênese concorda bastante bem com isto: Fichte obteve seu insight ligando-se a Kant e Reinhold e, assim, nas órbitas externas da teoria do eu como princípio de conhecimento. Mas ele a tirou dessas órbitas e a fez valer por si.

c. A nova exposição da doutrina da ciência ampliou a fórmula do eu: o eu se põe pura e simplesmente como se pondo. Pode-se muito bem percorrer a pré-história dessa ampliação. Conforme o próprio objeto, esse 'como' já resulta de um pensamento da resenha de Enesidemo: a faculdade de representação existe para a faculdade de representação ${ }^{43}$. $O$ eu é essencialmente ser-para-si. Mas só em 1798 Fichte concebeu que disso se deduz a consequência de um saber duplo no eu. Os ensaios no Jornal Filosófico (Philosophisches Journal) do ano de 1797 ainda não contêm nada disso. Nem mesmo a consequência menor, conforme a qual todo eu é explicitamente ter-a-si (Sichhaben), foi prontamente extraída por Fichte. Do contrário, ele nunca poderia ter falado da aparição de um eu a partir de um travo (Anstoß) que deve causar o 'si' da consciência.

87 A fórmula do eu que se põe 'como' ponente se deduz, no entanto, em continuidade com a 'Grundlage' de 1794. Como se sabe, essa obra ensina que da limitação do eu por uma contraposição se segue que seu pôr tem de ocorrer de um duplo modo. 0 não-eu tem de ser posto como limitado pelo eu, o eu como determinado pelo não-eu ${ }^{44}$. Essa fórmula do 'pôr como (als)' emerge aqui, pela primeira vez, no centro do pensamento. Ela indica apenas, primeiramente, que o eu se põe de um modo determinado - não como eu em geral. Ela não diz também que o resultado da posição tem de conduzir à consciência explícita da sua particularidade. No decorrer da obra, porém, ela admite esse sentido ${ }^{45}$. A ele corresponde, pois, a marcha do progresso na posição do eu, que Fichte também [226] denomina lei da reflexão $0^{46}$. A posição originária é esclarecida em uma cadeia de novas posições e trazida à consciência para o eu. $\mathrm{Na}$ parte prática da doutrina da ciência, essa lei da reflexão é até mesmo definida como consequência direta do conceito do eu. Ali, isso significa: "o eu deve pôr a si mesmo não só para alguma inteligência fora dele, mas ele deve se pôr para si mesmo, ele deve se pôr como posto por si mesmo" ${ }^{47}$. Com isso, está alcançada a fórmula de 1797. Mas ela ainda não é a fórmula fundamental de toda a doutrina da ciência. Isto é, nela o eu 'deve' se pôr como eu, o que significa: ele não está já posto para si.

d. 'Força na qual está inserido um olho' - essa terceira fórmula de Fichte também tem uma pré-história. A metáfora do olho é encontrada, pela primeira vez, na doutrina da ciência de 1798. Esse texto já se assenta sobre a nova compreensão de Fichte de que todo eu é essencialmente ser-para-si. E é justamente isso que Fichte intenta, inicialmente, quando ele fala do eu enquanto olho. $O$ contexto torna isso claro: o olho é o oposto do espelho ${ }^{48}$. A imagem no espelho é somente a imagem para alguém que a vê. No eu, porém, o espelho é ele próprio aquele que vê (sehend), ele se tornou olho. Desse modo, as imagens do espelho não são imagens de outro e para outro. As imagens do eu são imagens do seu próprio ver, vistas também por aquele que vê (das Sehende). Elas são dele e para ele mesmo. "O eu na doutrina da ciência é (...) um espelho que espelha a si mesmo, é imagem de si”.

[227] Essa metáfora ainda se distingue inteiramente da versão do ano de 1801. Falta o pensamento de que o olho está 'inserido' em um fazer. Tal pensamento encontra-se 
ainda longe de Fichte. Ele ainda deduz o olho do ato do eu ponente. Duas passagens do Sistema da doutrina dos costumes (1798) e da Destinação do homem (1800) mostram como se chegou a essa nova fórmula ${ }^{49}$. Nelas, Fichte diz que o olho é inserido. $O$ texto da doutrina dos costumes mostra mais claramente o contexto temático no qual isso se dá. Conforme ela, o eu encontra em si, tão logo ele faz uma experiência consigo, um impulso à autoatividade. Esse impulso é cego, mas, enquanto impulso do eu, ele tem de ser atribuído ao eu que o percebe. Isso ocorre na medida em que o eu o traz sob o domínio do conceito e, assim, o torna dependente do pensamento que se autoengendra. A doutrina dos costumes exprime isso da seguinte maneira: o eu consciente, atuante, se desprende do inconscientemente dado e, assim, submete-se ao 'domínio do conceito' ${ }^{50}$.

No mesmo contexto, a Destinação do homem faz uso da metáfora do olho: "eu (...) como que insiro olhos no impulso cego". Aqui também ainda é o eu que é responsável pelo impulso conter olhos. Isso corresponde ao pensamento da doutrina dos costumes. Mas produz um estado no qual olho e impulso estão internamente ligados entre si - um estado no qual seria possível esquecer sua proveniência a partir do ato. Impulso e olho são um mundo de ação (Tatwelt) fechado em si. Não se pode dizer que a Destinação do homem quis ensinar isso. Contudo, é a direção à qual a metáfora de Fichte aponta.

Mais tarde, Fichte acrescentou à passagem da doutrina dos costumes, que se encontra no fundamento do trecho da Destinação do homem, uma nota à margem (não datada). Ela diz: "olhos são inseridos no Um" ${ }^{1}$. Ela estava destinada a formular novamente o que, segundo o texto de 1798, ocorre no 'desprendimento' do eu da tendência dada. Com isso, porém, o sentido originário desse texto se alterou completamente. Agora, olhos são inseridos 'no Um'. Não pode mais se tratar, com isso, da tendência. Ela tinha seu lugar determinado no sistema da doutrina da ciência aplicada, [228] que investiga a origem da experiência da autoconsciência agente. $O$ 'Um', contudo, é no mínimo a pura força de ação (Tatkraft) do eu, talvez até já seja a vida divina da doutrina de 1801. Pertence, portanto, à fundamentação de toda a doutrina da ciência. E dele é agora dito que o olho lhe é inserido.

Temos, portanto, de constatar o seguinte fenômeno: Fichte construiu a metáfora do olho para designar a essência do eu fechado em si mesmo. Ele falou do olho 'inserido' primeiramente no contexto particular da doutrina dos costumes. Com isso, a metáfora tinha se tornado, junto com o pensamento que ela compreende, completa. Mas ela ainda estava subordinada ao ato absoluto do eu. Depois que essa doutrina se alterou, Fichte levou a metáfora de volta para o centro de sua doutrina da ciência. Doravante, ela era a formulação adequada dessa teoria que se entendia como docta ignorantia e, por isso, carecia das metáforas.

93 e. É uma das mais interessantes tarefas da interpretação de Fichte desvelar as razões dessa transformação. Nós mostramos que houve muitas razões objetivas que alteraram a interpretação da autoconsciência. Todavia, elas só se tornaram eficazes quando outros motivos também apontaram para a mesma direção. Não podemos aqui sequer enumerá-los. Somente uma indicação, que concerne imediatamente a teoria da autoconsciência, ainda pode ser dada.

Os intérpretes quase não deram ouvidos à afirmação de Fichte de que ele foi surpreendido pelo conflito do ateísmo quando ele estava prestes a completar a síntese suprema da filosofia. Essa é a síntese do mundo inteligível e do mundo sensível. Caso ela fosse conhecida, não se teria podido bradar: 'ateísmo'52. Desconfia-se dessa autointerpretação, considerando-a como uma justificação posterior. Essa opinião 
deveria ser testada - e a partir das seguintes razões: a doutrina de 1798 não apenas alterou a fórmula da autoconsciência, ela também forneceu à teoria uma estrutura totalmente diferente. $\mathrm{O}$ sistema da doutrina dos costumes foi acolhido na própria fundamentação - com a consequência de que a consciência moral se torna a autêntica estrutura fundamental do eu. Ao ocorrer isso, a descrição da consciência moral também pôde e teve de [229] ser alterada. Afinal, na 'Grundlage' de 1794 ela estava sob o conceito do eu. Dela se seguia, em primeiro lugar, o conceito do conhecimento; a tarefa moral era seu complemento mais digno. A nova descrição também começa com a doutrina do conhecimento, mas agora ela é apenas a introdução à definição do saber moral. Se esta está alcançada, então os estágios do conhecimento são obtidos retroativamente a partir dela e só com isso, então, são propriamente deduzidos ${ }^{53}$. O conceito da moralidade, contudo, é tomado como síntese dos dois mundos ${ }^{54}$. Fichte é inteiramente consciente de que essa descrição é mais profunda e mais adequada ao pensamento de Kant que aquela que ele próprio tinha dado anteriormente.

Com esse teorema, referido aqui apenas superficialmente, Fichte levou o conceito da autoconsciência a uma posição que se pode comparar com aquela de 1801. A autoconsciência é manifestação, mas a manifestação dela mesma, da autoconsciência, é apenas a manifestação (Erscheinung) de um fundamento, que para todo conhecimento é impensável. Conforme a doutrina de 1798, ela manifesta a lei do mundo inteligível; conforme a de 1801, a vida de Deus. Assim, Fichte pôde se ligar ao pensamento de 1798 quando novas experiências e outras razões o permitiram reconfigurar no todo a doutrina da ciência. Nem a nova fórmula do seu pensamento fundamental, nem a nova versão do seu sistema devem ser entendidas como acomodações.

\section{Panorama}

Um panorama deve ser por fim apresentado. Nosso ensaio sobre o insight originário de Fichte não tratou de todo o conjunto de suas proposições sobre a autoconsciência. Renunciou-se a colocar a importante pergunta sobre a relação de egoidade e individualidade. Quem diz 'eu', pensa nesse ser determinado, consciente de si mesmo. Cada um só pode falar de si enquanto 'eu'; não faz sentido gritar ao outro: 'você, eu aí!' O termo filosófico 'eu' não se deixa introduzir na linguagem da vida. Constatar isso não significa torná-lo ilegítimo. Significa salientar um problema. A consciência 'eu' individualiza. Mas ela o faz não como a verruga no queixo ou como a posição [230] em um time esportivo. A propriedade digna de reflexão dessa consciência é a de, ao mesmo tempo, também universalizar. Cada um é, pelo eu, individualizado. Ao dizer 'eu', já sabe de si mesmo. E cada um se sabe enquanto esse determinado $E_{s t e}{ }^{55}$ na medida em que diz de si a mesma coisa - ou seja: 'eu'. Essa unidade de singularidade e universalidade, que não pode ser especificada, pode facilmente ser interpretada se a entendemos como uma maneira de falar. Ela é, então, um referir, um indicador. Com isso, o problema está posto de lado. Mas, então, não é permitido a ninguém mais dizer: o 'eu' é um modo da consciência e, portanto, uma realidade à qual se faz referência. Se isso é consentido, então todo o problema retorna. E tem de ser consentido. Do contrário, não se poderia tornar compreensível de nenhum modo o que liga homens entre si através da razão.

Em suas ocasionais proposições sobre a autoconsciência, Kant tinha tratado desse problema. 'Eu' compreende uma dupla consciência, universalidade lógica e existência empiricamente determinada. Ele atribuiu imediatamente ambas, contudo, a dois 
sujeitos diferentes, à apercepção pura e à empírica, que, decerto, pertencem uma à outra, mas têm de ser bem distinguidas. Nisto, permaneceu sem consideração o fato de que o eu empírico enquanto eu também é universal, que o eu puro, pela mesma razão, também é um eu singular. Se prestamos atenção no aspecto formal, então essa dificuldade é da mesma espécie que aquela que foi tomada em consideração com o insight originário de Fichte. Singularidade e universalidade são, no eu real, tanto dois momentos na unidade originária quanto sujeito e objeto em seu saber de si.

Hegel foi aquele que acolheu esse problema kantiano. Ele experimentou a construção lógica das condições que têm de ser cumpridas para que um pensamento da unidade do eu como universal e singular seja possível. Portanto, ele também partiu de um problema que Kant não tinha tomado em consideração, só que de um outro problema que Fichte. Na teoria idealista da autoconsciência, por conseguinte, duas linhas nascem a partir de Kant. Uma leva diretamente a Hegel, a outra, a Fichte. O ponto de vista de Fichte é o saber-eu. 0 que ele ensina sobre a relação do eu-indivíduo com a egoidade nunca obteve a profundidade do seu insight originário, mesmo que tenha ultrapassado em muito os dicta acidentais de Kant.

[231] Pode-se ainda indicar outras passagens obscuras na doutrina fichteana do eu. Caso se tratasse de um inventário abrangente do problema 'autoconsciência', isso então também teria de ocorrer. Mas aqui tratou-se apenas de uma recordação do insight originário de Fichte. A filosofia o esqueceu; mais que isso, nunca tomou conhecimento dele. Esse insight não é, decerto, um conhecimento com o qual pode-se dar por satisfeito. Mas, até agora, ele nunca foi superado por ninguém. E ele mostra a quais exigências tem de estar submetida uma teoria que quer levar a luz do pensamento ao centro da consciência na qual nós nos compreendemos. Para quem essa luz só serve para descobrir trivialidades, faz bem em tomar outros caminhos.

Não seria demasiado difícil apresentar a prova de que os seguidores importantes de Fichte no terreno da teoria da autoconsciência sempre ainda poderiam ter aprendido com ele. Herbart se propôs verificar as intuições de Fichte com a ajuda de um método mais objetivo que o da doutrina da ciência. Mas ele nunca apresentou um fenômeno uniforme da 'autoconsciência', apesar de todo ensinamento que também se deve a ele. A fenomenologia transcendental de Husserl, apesar das muitas distinções frutíferas, sucumbe à crítica da teoria do eu como reflexão. Heidegger, decerto, minou a filosofia da autoconsciência, mas somente ao preço de simplesmente deixar de lado as questões objetivas trabalhadas por ela.

101 É preciso mesmo se lamentar que na história dos desdobramentos do idealismo o insight de Fichte tenha permanecido sem consequências. Foi o pensamento de Hegel que teve efeito. Contra ele, Fichte teria objetado duplamente: Hegel pensa a unidade dos opostos apenas dialeticamente, portanto, a partir do seu resultado. 0 fenômeno eu, porém, exige apreendê-los como unidade originária. Ademais, ele pensa a unidade de efetividade e liberdade somente como realização da liberdade, portanto, novamente, não como unidade originária de ambos. Cada desenvolvimento de opostos ocorre no espaço de sua unidade, que, primeiramente, torna possível seu movimento. E a liberdade já deve ser pensada em si como liberdade efetiva.

102 Muitos dos seguidores de Hegel também levantaram contra ele objeções desse tipo. Suas consequências, porém, nunca alcançaram o nível do insight de Fichte. Todos eles tendem a pré-ordenar abstratamente alguma efetividade ao eu, à razão e à [232] liberdade, e dizer que ela é aquilo de que dependemos. Com isso, o erro de Hegel é 
somente repetido, num contexto invertido, e tornado mais grosseiro. Só o fato (Faktum) da liberdade é pensado, não a liberdade enquanto fato. Neste caso, contudo, a pergunta sobre essência, unidade e origem do eu, tem de emudecer.

\section{Referências bibliográficas}

\section{NOTAS}

1. G. Gurwitsch, Fichtes System der konkreten Ethik, Tübingen 1924. - M. Gueroult, L'évolution et la structure de la Doctrine de la science, Paris 1930.

2. É importante observar aqui que o texto de Henrich é de 1966, e que hoje já temos acesso à edição crítica da obra completa de Fichte (N.T.).

3. $\mathrm{KrV}$ B 404, A 366.

4. Refl. 4220.

5. Sem dúvida, ao lado da teoria da reflexão, havia ainda, aos olhos de Kant, dois elementos de uma teoria mais abrangente da autoconsciência. Primeiro, ele se colocou a pergunta acerca da espécie de saber que o eu adquire no retorno sobre si mesmo. A imediatidade de seu ter-a-si (Sichhaben) sugere tomá-lo por um modo de intuição. Atividade, racionalidade e reflexividade indicam, no entanto, um conhecimento conceitual. De fato, a reflexividade exclui o pensamento do eu como intuição tão decisivamente quanto a imediatidade do ter exclui seu caráter conceitual. Como, de acordo com Kant, os elementos do conhecimento só podem ser intuição ou conceito, ele se restringiu, finalmente, à obscura informação de que o eu é uma 'consciência transcendental' (Refl. 5661). - Além disso, Kant estabeleceu também a diferença entre o si como consciência e a experiência de si. Esta última é o fundamento da distinção entre apercepção pura e empírica. Ela conduz ao problema de como a consciência da existência do eu está ligada com o estado de um sujeito do conhecimento que é consciente de si. - Esses dois elementos são próprios à doutrina kantiana e são inseparáveis dela. Mas se nos detemos neles mais precisamente, logo resultam dificuldades - particularmente quando tentamos pensá-los em conjunto com a teoria do eu como 
reflexão. A teoria da reflexão, porém, é, mesmo na filosofia crítica, o pensamento dominante sobre o eu. Ela é a fórmula para a representação sobre a essência da autoconsciência comum a uma época.

6. Cf. sobre o assunto: H. Schmitz, System der Philosophie I, Bonn 1964, p. 249 e seguintes.

7. Nl. 365. Na sequência as obras de Fichte são citadas segundo a edição de I. H. Fichte, e segundo o volume e o número da página. A elas se acrescenta: J. G. Fichte, Escritos dos anos 1790-1800, editados por Hans Jacob, Berlin 1937, citado como 'Nl' (Nachgelassene Schriften) e com o número de página.

8. Akademieausgabe, vol. XX, p. 270.

9. SW I, p. 98.

10. O comum entre o problema de Fichte e as reflexões das quais parte Wolfgang Cramer é a passagem de uma crítica da teoria do saber enquanto relação para uma teoria do saber enquanto produção. Cf., CRAMER, W. Die Monade (Stuttgart, 1960), p. 56, 60 e Das Grundproblem der Philosophie. Beilage zu 'Diskus', (Frankfurt am Main, mesma data), p. 59 - nota.

11. De um golpe, subitamente [N.T.].

12. SW I, p. 459.

13. Nl, p. 357.

14. SW I, p. 528.

15. Idem.

16. SW I, p. 274.

17. Jacobi an Fichte. In: Die Schriften zu J. G. Fichtes Atheimusstreit. Ed. H. Lindau. Munich, 1912; p. 189.

18. Nl. p. 356.

19. WW II, p. 442 ss. Esse termo foi introduzido no pensamento atual por Husserl. Na sua obra, assim como em Heidegger, ele tem um tom polêmico contra a pretensão dedutiva do idealismo. É realmente digno de nota que ele tenha sido utilizado primeiramente por Fichte, e, mais ainda, por tê-lo sido no esclarecimento da estrutura do eu.

20. Nesta forma, primeiramente, em WW II, p. 444, 448.

21. Segue o grifo original em itálico: eingesetzt (N.T.)

22. O texto alemão esclarece aqui uma diferença no uso dos verbos auxiliares werden e sein na construção da voz passiva, em que um (werden) indica a voz passiva de um processo: "algo é feito", e o outro (sein) a voz passiva de um estado, no qual o processo já se realizou: "algo está feito". Henrich faz uso dessa distinção para indicar que o olho não é algo inserido no eu em um processo, mas que já está com ele inserido. (N.T.)

23. WW XI, p. 18. As passagens que contêm a fórmula do olho na Doutrina da Ciência de 1801 (WW II, p. 19, 37) encontram-se em contexto um pouco diferente. A essa diferença corresponde uma mudança no sistema da doutrina da ciência, da qual, porém, é lícito abstrair no presente contexto.

24. No espólio de Fichte em Berlin, Kapsel IV, 7. Devo agradecer imensamente ao senhor Dr. Hans Jacob do Fichte-Archiv da Academia Bávara das Ciências por sua múltipla ajuda. Ainda não se tem muita clareza acerca da decifração das palavras entre parênteses no texto.

25. Fichte também denomina essa quintuplicidade 'período sintético' (NL. 529). Só na doutrina da ciência de 1798 ele entra em cena. Passagens importantes sobre a quintuplicidade sintética são as seguintes: SW II, p. 35, X, p. 48, 121, 296/7, 350 ss.

26. SW X, p. 357.

27. SW X, p. 259.

28. SW X, p. 61.

29. SW X, p. 259.

30. Dois dos três sonetos estão impressos nas obras duas vezes (VIII, p. 461/2, XI, p. 347/8), com a correta justificação de que Fichte "quase em nenhum outro lugar enunciou mais claramente a 
essência da sua filosofia". No terceiro soneto, a edição do décimo primeiro volume difere daquela do oitavo volume. Esta, porém, é uma fiel repetição do original, como mostra uma comparação com o manuscrito do terceiro soneto, que somente agora está acessível. A datação resulta do papel, que provém da fábrica de papel Ebart. Fichte fez uso dele no ano de 1812 para os manuscritos das suas preleções e, provavelmente, o teve à disposição um pouco mais cedo ou mais tarde. Mesmo o relato do sonho (cf. idem, p. 24) está escrito no mesmo papel (conforme as generosas informações do Sr. Dr. Jacob).

31. Este soneto junto com os outros dois foram traduzidos para o português por Paulo Roberto Licht dos Santos e publicados nos Cadernos de Filosofia Alemã , no 10 (2002), pp. 101-114. Dada a qualidade literária da tradução, optamos por reproduzi-la aqui. Para comparação, eis as duas estrofes selecionadas por Henrich em alemão:"Dies ists. Seit in Urania's Aug', die tiefe / sich aber klare, blaue, stille, reine / Lichtflamm', ich selber still hineingesehen/ Seitdem ruht dieses Aug' mir in der Tiefe / Und ist in meinem Seyn, - das ewig Eine / Lebt mir im Leben, sieht in meinem Sehen". (N.T.)

32. SW VIII, p. 425.

33. Há de se notar que, nesse percurso, são atribuídos ao 'absoluto' os caracteres que em 1797 eram do eu.

34. Assim, mostra-se que a teoria tardia de Fichte conduz ao pensamento de um fundamento que, no pensar, não pode ser desconsiderado e que, contudo, é algo totalmente outro que um 'conceito necessário da razão'. Isso é o que há de comum entre Fichte e o pensamento da prova ontológica de Deus. A Docta ignorantia de Fichte distingue-se desta última negativamente, na medida em que ela não admite descrever nosso saber de Deus como conhecimento da realidade de um conceito. Ela a supera por poder tomar uma das suas intenções mais seriamente, mais até que o próprio Schelling pôde: ela pode descrever 'Deus' como o verdadeiramente Efetivo em nosso conhecimento, antes da autoconsciência e da moralidade. Desse modo, resulta uma conexão entre as tradições da ontoteologia e a doutrina do primado da razão prática. Ela é também adequada para tornar visível suas pressuposições comuns, ainda ocultas, mas atuantes desde o início. Cf. do autor Der ontologisches Gottes Beweis, Tübingen, 1960 e nela a perspectiva discutida na p. 266.

35. Curiosamente Henrich parece referir-se aqui ao texto que já estava disponível na edição do Nachgelassene Schriften citada por ele. O texto, proveniente do manuscrito de um aluno não identificado (transcrição de Halle), foi publicado primeiramente por Hans Jacob em 1937, e após a descoberta, em 1980, de outra transcrição do mesmo curso (transcrição de Krause), editou-se o que hoje conhecemos por Wissenschaftslehre Nova Methodo. (N.T.)

36. SW I, p. 458/9.

37. NI. p. 355 ss.

38. NI. p. 357.

39. SW II, p. 444.

40. SW I, p. 11, 16.

41. SW VIII, p. 425.

42. Cf. W. Kabitz, Studien zur Entwicklungsgeschichte der Fichteschen Wissenschaftslehre, 1902.

43. SW I, p. 11.

44. SW I, p. 125, 127.

45. Idem, p. 223, 227.

46. Já se chamou atenção para o uso fichteano do termo 'reflexão'. Conforme a 'Grundlage' de 1794, é uma lei do eu de se refletir sobre si mesmo, isto é, de se tornar consciente de suas posições. Ela se segue da essência do eu de pôr-se como determinado, mas não vale para o primeiro ato da posição no eu absoluto. Sobretudo a 'teoria da representação' e o 'Grundriss des Eigentümlichen (...)' (1795) têm a lei da reflexão como pressuposição metodológica. A partir de 1801 o eu também é pensado através da reflexão, mas agora conforme um conceito de reflexão que é diretamente oposto ao modelo da teoria, que denominamos 'teoria do eu enquanto reflexão'. A 
forma fundamental do saber "reflete nela mesma, (...) ela não o faz propriamente, mas ela o é" (SW II, p. 41). Fichte também fala do 'reflexo fundamental' (Grundreflex) em oposição à operação da reflexão, particularmente de modo enfático contra Schelling na carta de 15.01.1802 (Cartas, ed. Schulz II, p. 350).

47. SW I, p. 274.

48. NI. p. 377.

49. SW IV, p. 33A; SW II, p. 249.

50. Idem, ibidem.

51. Idem, ibidem.

52. Cartas, ed. Schulz II, p. 323.

53. NI. p. 467, cf. p. 493, 516.

54. NI. p. 476, cf. também SW I, p. 467.

55. Pronome substantivado no original. (N.T.) 